\title{
Revision of Sthenelais Kinberg, 1856, Fimbriosthenelais Pettibone, 1971 and Eusthenelais McIntosh, 1876 (Polychaeta, Sigalionidae) in the Northeast Atlantic
}

\author{
Ruth BARNICH ${ }^{1, *} \&$ Ton VAN HAAREN ${ }^{2}$ \\ ${ }^{1}$ Senckenberg, Forschungsinstitut und Naturmuseum Frankfurt, Marine Evertebraten II, \\ Senckenberganlage 25, D-60325 Frankfurt, Germany. \\ ${ }^{1}$ Thomson Environmental Consultants, Compass House, Surrey Research Park, \\ Guildford, GU2 7AG, United Kingdom. \\ ${ }^{2}$ Eurofins AquaSense, H.J.E., Wenckebachweg 120, 1114AD, Amsterdam-Duivendrecht, Netherlands. \\ *Corresponding author: ruth.barnich@senckenberg.de \\ ${ }^{2}$ Email: tonvanhaaren@eurofins.com \\ ${ }^{1}$ urn:1sid:zoobank.org:author:F1E3AEB7-0C77-41BB-8A6C-F8B429F17DA1 \\ ${ }^{2}$ urn:lsid:zoobank.org:author:4913E25D-12EF-4D31-A7D1-39E0A805D4F7
}

\begin{abstract}
Two common sigalionid species from the Northeast Atlantic, Sthenelais boa (Johnston, 1833) and S. limicola (Ehlers, 1864), have never been revised in detail. Although their validity has never been questioned, a number of taxonomic problems related to Sthenelais Kinberg, 1856 and the later established Fimbriosthenelais Pettibone, 1971 remain unresolved. The validity of F. minor (Pruvot \& Racovitza, 1895 ) has been repeatedly discussed, but no agreement reached. Also the validity of Fimbriosthenelais has been at stake, affecting the generic assignment of Fimbriosthenelais zetlandica (McIntosh, 1876), another species present in the area. Among the investigated species of Sthenelais, some where thought to be synonyms of Eusthenelais hibernica McIntosh, 1876, which led us to also include Eusthenelais McIntosh, 1876. We also re-examined Eusthenelais abyssicola McIntosh, 1879, the only other species attributed to the genus, and confirm that it is indeterminable. In total, we investigated 37 nominal taxa reported from the Northeast Atlantic and as a result we consider only five species to be valid: Sthenelais boa, S. limicola, Fimbriosthenelais zetlandica, F. longipinnis (Grube, 1869) and Eusthenelais hibernica. These genera and species are described and discussed herein and an updated identification key to all Northeast Atlantic species of Sigalioninae Gonzalez et al., 2018 is given.
\end{abstract}

Keywords. Taxonomy, terminology, identification key, Sigalioninae.

Barnich R. \& Van Haaren T. 2021. Revision of Sthenelais Kinberg, 1856, Fimbriosthenelais Pettibone, 1971 and Eusthenelais McIntosh, 1876 (Polychaeta, Sigalionidae) in the Northeast Atlantic. European Journal of Taxonomy 740: 138-171. https://doi.org/10.5852/ejt.2021.740.1287

\section{Introduction}

Species attributed to the genus Sthenelais Kinberg, 1856 have been among the earliest described sigalionids in the wider Northeast Atlantic (i.e., including the Mediterranean Sea): Sthenelais boa 
(Johnston, 1833) and S. limicola (Ehlers, 1864) are widely distributed in the area, with both found nearshore and S. limicola also regularly present in offshore habitats. Both species have regularly been reported in the literature (see respective synonymy paragraphs below), but so far they have not been included in any detailed revision of the genus.

Sthenelais Kinberg,1856 was initially established for Sthenelais helenae Kinberg, 1856 from Chile (Southeast Pacific). Pettibone (1971) revised several species of the genus and established the new genera Willeysthenelais Pettibone, 1971 and Fimbriosthenelais Pettibone, 1971. With the presence of very long papillae at the basis of the ventral cirri Willeysthenelais is easily distinguished from the other two genera; species attributed to Willeysthenelais are not reported for the area and not treated further in this study.

The distinction between Sthenelais and Fimbriosthenelais is rather subtle. Both genera as defined by Pettibone (1971) have very similar parapodia, lacking any long basal papillae on the ventral cirri, and differ by the presence (Fimbriosthenelais) or absence (Sthenelais) of papillae on the parapodial stylodes, which are club-shaped or elongate structures located at the margin of bracts or distally on lobes.

A major problem we encountered during this study is the inconsistency of terminology found throughout the literature, especially with regard to parapodial structures and terms such as papillae, fimbriae, etc. Below, we establish a standardised terminology, which will enable us to differentiate more clearly between the species described.

Among the species of Sthenelais moved to Fimbriosthenelais by Pettibone (1971) was Sthenelais minor Pruvot \& Racovitza, 1895. The type material of S. minor being lost (type locality near Banyuls, Western Mediterranean), Pettibone based her redescription on material from Brest described by Saint-Joseph (1899) as Sthenelais minor?.

Chambers \& Muir (1997) re-examined Saint-Joseph's specimen and considered it to be a juvenile of Sthenelais boa as they could not confirm the presence of well defined papillae on the stylodes of this specimen. They noted too, that small specimens of $S$. boa may have a few papillae on some stylodes, that their elytra were covered by sand grains and that simple neuropodial chaetae were present, all of which are distinguishing characters of $F$. minor as redescribed by Pettibone. Chambers \& Muir (1997) also moved Sthenelais zetlandica McIntosh, 1876 back from Fimbriosthenelais to Sthenelais without further comments or analysis of the genera and species involved.

Barnich \& Fiege (2003) and later Gil (2011) discussed the potential synonymy of $F$. minor with $S$. boa and the taxonomic implications regarding the validity of the genus Fimbriosthenelais without reaching a final conclusion. Today, with many more specimens, type material and extensive literature studied, we are able to present a long overdue revision of species attributed to Sthenelais and morphologically similar genera in the Northeast Atlantic and Mediterranean Sea.

In the recent literature, three species of Sthenelais and three species of Fimbriosthenelais have been reported from the area (Barnich \& Fiege 2003; Gil 2011; Núñez et al. 2015):

Sthenelais boa (Johnston, 1833);

Sthenelais jeffreysi McIntosh, 1876 (status needs clarification, see Gil 2011);

Sthenelais limicola (Ehlers, 1864);

Fimbriosthenelais longipinnis (Grube, 1869);

Fimbriosthenelais minor (Pruvot \& Racovitza, 1895) (status needs clarification, see Gil 2011);

Fimbriosthenelais zetlandica (McIntosh, 1876). 
The suggested synonymy of Sthenelais jeffreysi McIntosh, 1876 and S. heterochaeta McIntosh, 1897 with Eusthenelais hibernica McIntosh, 1876 (see Eliason 1962; Gil 2011), leads us to also include Eusthenelais McIntosh, 1876 in this study. However, the presence of dorsal cirri on segment 3 puts this genus closer to Neoleanira Pettibone, 1970 and clearly differentiates it from Sthenelais and Fimbriosthenelais, which lack any dorsal cirri (see McIntosh 1876b, 1900; Amoureux 1972; Núñez et al. 2015). Table 1 gives a summary of all important generic characters discussed herein.

In total, we investigated 37 nominal taxa attributed to Sthenelais, Fimbriosthenelais and Eusthenelais present in the wider Northeast Atlantic. Table 2 summarises the current status of these taxa; further details are found in the Synonymy and Remarks sections below.

The current revision is restricted to material from the Northeast Atlantic and the Mediterranean Sea; records of the species under consideration outside this area should be treated carefully and need further confirmation. Based on the results of this revision an updated identification key to all species of the subfamily Sigalioninae Gonzalez et al., 2018 found in the area is given below.

\section{Material and methods}

The type and additional specimens investigated for this study are deposited in the collections of the following institutions: Eurofins TvH collection, Amsterdam; National Museums Scotland (NMS); Natural History Museum of Denmark (NHMD); Senckenberg Natural History Museum, Frankfurt (SMF); The Natural History Museum, London (BMNH); Thomson Environmental Consultants, Guildford (TUM).

Specimens were studied using Leica MZ9.5 and WILD M8 stereo microscopes and Nikon Eclipse E400 and Leica Diaplan compound microscopes, the latter equipped with Nomarski interference contrast. Drawings are based on digital photographs taken with a Canon PowerShot G12 and finalised using Procreate and Photoshop.

In figures of anterior ends, the anteriormost elytra were either missing or removed.

Evaluation of parapodial bracts and lobes requires careful examination. Localising bracts and stylodes is best achieved on a detached, but unmounted parapodium under the stereo microscope. In order to assess the presence of papillae on the stylodes, the parapodium needs to be mounted on a slide with a coverslip and examined at higher magnification using a compound microscope.

The length of the specimens is measured from the anterior margin of the prostomium to the posterior border of the last segment (pharynx not included, if everted), while the width is taken at the widest segment, including parapodia but excluding chaetae. Sigalionids are long-bodied and often fragmented; thus, comparing the length of individuals is rather difficult. But the width (being maximal in the anterior body region) is rather easy to measure and thus most useful for comparing body sizes.

\section{Terminology}

A general overview of the terminology used in the identification of sigalionid genera is given in Aungtonya (2003). The most important identification characters used in this revision are illustrated in detail in Figs 1-2 (anterior end and parapodia of Sthenelais limicola) and Fig. 3 (stylodes and digitiform extensions on parapodia of $S$. boa). Understanding and correctly assessing the different appendages on the prostomium and anterior part of the body can be rather challenging: they tend to be entangled after fixation or may be missing. We follow Aungtonya \& Eibye-Jacobsen (2018) in using "dorsal tentacular crest" instead of "ctenidium" (see Pettibone 1971) for the structure present dorsally on the tentaculophores in all generic diagnoses presented herein. 
Table 1. Diagnostic generic characters of Sthenelais Kinberg, 1856, Fimbriosthenelais Pettibone, 1971 and Eusthenelais McIntosh, 1876.

\begin{tabular}{|c|c|c|c|}
\hline Character / Genus & Sthenelais & Fimbriosthenelais & Eusthenelais \\
\hline \multicolumn{4}{|c|}{ Prostomium } \\
\hline Length of lateral antennae & $\begin{array}{l}\text { Distinctly shorter than } \\
\text { dorsal tentacular cirri }\end{array}$ & $\begin{array}{l}\text { Distinctly shorter than } \\
\text { dorsal tentacular cirri }\end{array}$ & $\begin{array}{l}\text { As long as dorsal tentacular } \\
\text { cirri }\end{array}$ \\
\hline \multicolumn{4}{|c|}{ Segment 3} \\
\hline Pair of dorsal cirri & Absent & Absent & Present \\
\hline \multicolumn{4}{|c|}{ Neuropodia } \\
\hline Stylodes & $\begin{array}{l}\text { Smooth (occasionally } \\
\text { minutely papillated) }\end{array}$ & Distinctly papillated & Smooth \\
\hline Shape of posterior bract & Bilobed & Bilobed or truncate & Bilobed \\
\hline \multicolumn{4}{|c|}{ Neurochaetae } \\
\hline Compound falcigers & Present (numerous) & Present (numerous) & Present (numerous) \\
\hline Compound spinigers & Absent or present (few) & Absent & Present (numerous) \\
\hline Simple spinous chaetae & Absent or present (few) & Absent or present (few) & Absent \\
\hline
\end{tabular}

Also, the parapodial characters are not always easy to examine due to the presence of various bracts and lobes showing a variable number of stylodes and/or digitiform extensions (Fig. 3). Based on the revision of Pettibone (1971), we describe the basic parapodial characters of the genera considered herein as follows:

The parapodia are biramous, each with up to three cup-shaped ctenidia dorsal to the notopodia (Fig. 2AB). The notopodial acicular lobe is nearly completely encircled by a bract covering the basis of the capillary notochaetae (Fig. 2A, notopodial bract). The neuropodial acicular lobe is posteriorly nearly completely covered by a bilobed or truncate bract and presents anteriorly two smaller crescent-shaped bracts (Fig. 2A-B: bilobed neuropodial posterior bract, neuropodial anterodorsal and anteroventral bracts). From these three neuropodial bracts, three groups of neurochaetae emanate: the middle (posterior) group with stout compound falcigers and occasionally compound spinigers; the upper (anterior) group with slender compound falcigers and occasionally compound spinigers and/or simple, spinous chaetae; and the lower (anterior) group with slender compound falcigers.

As defined by Pettibone (e.g., 1970, 1971) parapodial stylodes are club-shaped or elongate structures, resembling giant papillae, present marginally on the bracts or distally on the lobes. Because stylodes can be covered by small papillae, there was a need for another descriptive term for these characteristic structures.

Unfortunately, the description by Pettibone (1971) of the parapodial stylodes and other characters found on the margin of the bracts of the different species is not consistent. When establishing her new genus, Pettibone stated: "The genus Fimbriosthenelais is named for the characteristic fimbriated or papillated parapodial stylodes."

However, the terms "papillae/papillated" and "fimbriae/fimbriated" are used for different morphological structures in her revision: stylodes of species of Fimbriosthenelais are described as being fimbriated or papillated (i.e., covered by fimbriae = papillae). And also, the margin of the neuropodial bracts in species 
Table 2. Status of all nominal taxa attributed to Sthenelais Kinberg, 1856, Fimbriosthenelais Pettibone, 1971 and Eusthenelais McIntosh, 1876 in the Northeast Atlantic and Mediterranean Sea.

\begin{tabular}{|c|c|}
\hline Taxon name & Current designation and remarks \\
\hline Aphrodita arcta Dalyell, 1853 & $\begin{array}{l}\text { ? Sthenelais limicola: see McIntosh (1900), no type material } \\
\text { available, description insufficient }\end{array}$ \\
\hline Conconia Schmarda, 1861 & $\begin{array}{l}\text { Sthenelais Kinberg, 1856: type species Conconia caerulea } \\
\text { Schmarda, 1861 = Sthenelais helenae Kinberg, } 1856 \text { (see } \\
\text { Pettibone 1971) }\end{array}$ \\
\hline Eusthenelais McIntosh, 1876 & Accepted: type species Eusthenelais hibernica McIntosh, 1876 \\
\hline Eusthenelais abyssicola McIntosh, 1879 & $\begin{array}{l}\text { Indeterminable sigalionid: holotype BMNH 1921.5.1.622 } \\
\text { (examined herein) unidentifiable and description insufficient }\end{array}$ \\
\hline Eusthenelais hibernica McIntosh, 1876 & Accepted \\
\hline Fimbriosthenelais Pettibone, 1971 & $\begin{array}{l}\text { Accepted: type species Fimbriosthenelais longipinnis } \\
\text { Grube, } 1869\end{array}$ \\
\hline Fimbriosthenelais longipinnis (Grube, 1869) & Accepted \\
\hline Fimbriosthenelais zetlandica (McIntosh, 1876) & Accepted \\
\hline Parasthenelais Amoureux, 1972 & $\begin{array}{l}\text { Eusthenelais McIntosh, 1876: type species Eusthenelais } \\
\text { hibernica McIntosh, } 1876 \text { (unjustified name change) }\end{array}$ \\
\hline Sigalion boa Johnston, 1833 & Sthenelais boa (Johnston, 1833) \\
\hline Sigalion carringtonii Carrington, 1865 & $\begin{array}{l}\text { Sigalion mathildae Audouin \& Milne Edwards, 1832: see } \\
\text { Mackie \& Chambers (1990) }\end{array}$ \\
\hline Sigalion Estellae Guérin-Méneville, 1843 & $\begin{array}{l}\text { ? Sthenelais boa: see Fauvel (1923), no type material } \\
\text { available, description insufficient }\end{array}$ \\
\hline Sigalion Idunae Rathke, 1843 & Sthenelais boa (Johnston, 1833) \\
\hline Sigalion limicola Ehlers, 1864 & Sthenelais limicola (Ehlers, 1864) \\
\hline Sthenelais Kinberg, 1856 & Accepted: type species Sthenelais helenae Kinberg, 1856 \\
\hline Sthenelais atlantica McIntosh, 1876 & Fimbriosthenelais zetlandica (McIntosh, 1876) \\
\hline Sthenelais Audouinii Quatrefages, 1866 & $\begin{array}{l}\text { ? Sthenelais boa: see Fauvel (1923), no type material } \\
\text { available, description insufficient }\end{array}$ \\
\hline Sthenelais boa (Johnston, 1833) & Accepted \\
\hline Sthenelais ctenolepis Claparède, 1868 & Sthenelais boa (Johnston, 1833) \\
\hline Sthenelais dubiosa Horst, 1917 & Fimbriosthenelais longipinnis (Grube, 1869) \\
\hline Sthenelais Edwardsii Quatrefages, 1866 & $\begin{array}{l}\text { ? Sthenelais boa: see Fauvel (1923), no type material } \\
\text { available, description insufficient }\end{array}$ \\
\hline Sthenelais filamentosus Ditlevsen, 1917 & Sthenelais limicola (Ehlers, 1864): syn. nov. \\
\hline Sthenelais fuliginosa Claparède, 1868 & Sthenelais boa (Johnston, 1833) \\
\hline Sthenelais haddoni McIntosh, 1897 & Sthenelais limicola (Ehlers, 1864): syn. nov. \\
\hline Sthenelais heterochaeta McIntosh, 1897 & $\begin{array}{l}\text { Eusthenelais hibernica McIntosh, 1876: synonymy } \\
\text { according to Eliason (1962), confirmed }\end{array}$ \\
\hline Sthenelais jeffreysi McIntosh, 1876 & $\begin{array}{l}\text { Eusthenelais hibernica McIntosh, 1876: synonymy } \\
\text { according to Eliason (1962), confirmed }\end{array}$ \\
\hline Sthenelais Leidyi Quatrefages, 1866 & $\begin{array}{l}\text { ? Sthenelais: Sthenelais boa according to Pettibone (1963), } \\
\text { but no type material available, description insufficient }\end{array}$ \\
\hline Sthenelais leiolepis Claparède, 1868 & Sthenelais limicola (Ehlers, 1864) \\
\hline Sthenelais limicola (Ehlers, 1864) & Accepted \\
\hline Sthenelais longipinnis Grube, 1869 & Fimbriosthenelais longipinnis (Grube, 1869) \\
\hline Sthenelais minor Pruvot \& Racovitza, 1895 & Sthenelais boa (Johnston, 1833): syn. nov. \\
\hline Sthenelais minor var. digitata Fauvel, 1919 & $\begin{array}{l}\text { Fimbriosthenelais hirsuta (Potts, 1910): not } \\
\text { Fimbriosthenelais longipinnis, see Wehe (2007) }\end{array}$ \\
\hline Sthenelais papillosa Day, 1960 & Fimbriosthenelais zetlandica (McIntosh, 1876) \\
\hline Sthenelais Sarsi McIntosh, 1897 & Fimbriosthenelais zetlandica (McIntosh, 1876) \\
\hline Sthenelais vachoni Rullier, 1964 & Fimbriosthenelais zetlandica (McIntosh, 1876) \\
\hline Sthenelais variabilis Potts, 1910 [part, var. glabra] & Fimbriosthenelais longipinnis (Grube, 1869) \\
\hline Sthenelais? zetlandica McIntosh, 1876 & Fimbriosthenelais zetlandica (McIntosh, 1876) \\
\hline
\end{tabular}


of Fimbriosthenelais and Sthenelais is described as being fimbriated (but shows digitiform extensions, also referred to as "papillae" by Pettibone). Additionally, "papillae" cover the ventral body surface in Fimbriosthenelais.

In our understanding, the difference between a papilla and an extension in this context is the degree of separation from the supporting structure: a papilla is more or less separated and placed on top of the structure, whereas an extension is part of the considered structure. Consequently, we propose an adjusted terminology for the different characters discussed here:

'Papillae' = globular or elongate (separated) structures on stylodes or body surface; papillae often have minute sensorial hairs distally.

'Extensions' = digitiform projections of variable length being part of the margin of the neuropodial bracts; a single extension can bear minute papillae and/or sensorial hairs.

Another problematic term used by Pettibone (1971) is "fimbriate with stylodes" referring to the neuropodial bracts of $F$. zetlandica for example. In our understanding, the margin of the bract in this species is more or less straight and carries stylodes (Fig. 6D-E), but there are no digitiform marginal extensions as in S. boa for example (Figs 3, 4D-E).

And finally, while the genus Fimbriosthenelais was established for species with fimbriated/papillated stylodes, "fimbriated" neuropodial bracts (sensu Pettibone) are not only found in Fimbriosthenelais, but also in some Sthenelais species such as $S$. helenae, type species of the genus, and in S. boa (Figs 3, 4D-E).

Therefore, we suggest not to use "fimbriated" in descriptions of the neuropodial bracts; they have either digitiform extensions or they carry stylodes. This allows for "fimbriae/fimbriated" to be used only in the sense of papillae which cover the stylodes and are the diagnostic character of the genus Fimbriosthenelais.

The three genera considered here present several types of chaetae: spinous capillaries (i.e., slender chaetae with transverse rows of spines and a long capillary tip, which can be simple or bidentate; Fig. 4F), simple spinous chaetae (i.e., moderately stout chaetae with transverse rows of spines in their distal part and a short, pointed, simple tip; Figs 2E, 4G), compound falcigers (i.e., chaetae consisting of a stem and a single or multi-articled blade with a typically curved, bidentate tip; Figs 2D, F-G; 4H-I, $6 \mathrm{~F}-\mathrm{H}, 8 \mathrm{~F}-\mathrm{G}$ ), compound spinigers (i.e., chaetae consisting of a stem and a multi-articled blade with a simple, pointed tip; Figs 2C, 8E).

\section{Results}

\section{Taxonomy}

Class Polychaeta Grube, 1850

Family Sigalionidae Kinberg, 1856

Subfamily Sigalioninae Gonzalez et al., 2018

Genus Sthenelais Kinberg, 1856 (emended)

Sthenelais Kinberg, 1856: 387 (type species Sthenelais helenae Kinberg, 1856; revised by Pettibone 1971).

Conconia Schmarda, 1861: 150 (type species Conconia caerulea Schmarda, 1861 = Sthenelais helenae Kinberg, 1856). 


\section{Diagnosis}

BoDy. Elongate, with numerous segments; mid-dorsum bordered by few pairs of small ctenidia.

ELYTRA. Numerous, on segments 2, 4, 5, 7, continuing on alternate segments to 27, then on every segment to end of body. Dorsal tubercles on segments 3, 6, 8, continuing on alternate segments to 26 .

Prostomium. Rounded, fused to first segment. Median antenna inserted terminally, with stout, cylindrical ceratophore with lateral auricles and tapering style. Lateral antennae fused to inner dorsal sides of tentaculophores, without ceratophore, distinctly shorter than dorsal tentacular cirri. Paired palps encircled by palpal sheath emerging ventrally to tentaculophores.

TENTACUlophores. With single aciculum, a pair of tentacular cirri, two bundles of capillary chaetae, L-shaped inner tentacular lobe with ciliated ridge and fused to palpal sheath, and dorsal tentacular crest.

SEgment 2. With first pair of elytra, biramous parapodia and buccal cirri longer than following ventral cirri. Small ctenidia on lateral lips and medial to ventral cirri in anterior segments.

SEgment 3. With dorsal tubercles fused to posterior sides of elytrophores of segment 2. Dorsal cirri absent.

BranCHIAE. Cirriform, absent in anteriormost segments.

DORSAL CIRRI. Absent from all segments.

VENTRAL CIRRI. Styles with or without basal knob and without long basal papillae.

PARAPODIA. Biramous, each with up to three cup-shaped ctenidia dorsal to notopodia, noto- and neuropodial acicular lobes with accessory bracts and smooth stylodes on most parapodia (minute papillae may be present on stylodes in juveniles or in anteriormost parapodia of adults). Notopodial acicular lobes nearly completely encircled by a bract covering the basis of the notochaetae. Neuropodial acicular lobes posteriorly with a large bilobed bract and anteriorly with two smaller crescent-shaped bracts.

CHAETAE. Notochaetae slender, spinous, tapering to capillary, uni- or bidentate tip. Neurochaetae usually compound falcigers and, if present, few compound spinigers and/or simple spinous chaetae; stems of compound chaetae usually with few rows of spines distally. Neurochaetae arranged in three groups: upper group of neurochaetae within anterodorsal bract: mainly slender compound falcigers; few simple, spinous chaetae (may be missing); in some species also few compound spinigers. Middle group of neurochaetae within posterior bract: all stout compound falcigers. Lower group of neurochaetae within anteroventral bract: all slender compound falcigers.

\section{Remarks}

The generic diagnosis of Sthenelais is emended for the potential presence of minute papillae on the stylodes found in juveniles or in anteriormost parapodia of adult $S$. boa and for the presence of compound spinigers found in S. limicola (see below).

Wehe (2007) was the first to mention that the capillary notochaetae of $S$. boa taper to a bidentate or unidentate tip and emended the generic diagnosis of Sthenelais accordingly. We confirm the presence of bidentate and unidentate (i.e., simple) tips for the capillary notochaetae of $S$. boa, while those of S. limicola are all simple, see below. 
Based on our study, Sthenelais currently comprises two valid species in the wider Northeast Atlantic: Sthenelais limicola (Ehlers, 1864), which is the most widespread and common nearshore and offshore, and Sthenelais boa (Johnston, 1833), which is found usually nearshore.

For an extensive list of synonyms, or species previously referred to Sthenelais, which belong to other genera, or species that require further investigation, see Table 2 and the respective paragraphs below.

\section{Sthenelais limicola (Ehlers, 1864) (emended)}

Figs $1-2$

Sigalion limicola Ehlers, 1864: 120.

Sthenelais leiolepis Claparède, 1868: 406-409, pl. 4 fig. 3, pl. 6 fig. 1 (description sufficient; see also Barnich \& Fiege 2003).

Sthenelais haddoni McIntosh, 1897a: 403. Syn. nov.

Sthenelais filamentosus Ditlevsen, 1917: 50, pl. 4 fig. 6, pl. 5 fig. 9. Syn. nov.

? Aphrodita arcta Dalyell, 1853: 170, pl. 24 fig. 14 (see McIntosh 1900; however, description insufficient).

Sthenelais limicola - Pruvot \& Racovitza 1895: 473, pl. 20 figs 122-123. - McIntosh 1900: 417, pl. 29

fig. 3, pl. 31 fig. 6, pl. 34 figs 9-11, pl. 42 figs 1-4. — Fauvel 1923: 113, fig. 42a-g. — Chambers 1985: 29-30, figs 1b, 2a, 15b-c, 21b-e. - Hartmann-Schröder 1996: 83 fig. 28. — Chambers \& Muir 1997: 158, fig. 51. — Barnich \& Fiege 2003: 132, fig. 65. — Gil 2011: 947. — Núñez et al. 2015: 244, fig. 98.

\section{Diagnosis}

Dorsal cirri absent on segment 3. Ventral body surface smooth. Outer elytral margin with irregular extensions (anterior elytra) or notched (posterior elytra); elytral surface smooth, except for some microtubercles near anterior margin. Parapodial stylodes smooth, slender, cirriform; notopodia with few long dorsal papillae; margins of anterior neuropodial bracts smooth. Notochaetae tapering to simple capillary tip.

Type material (examined)

The types of Sthenelais filamentosus were available for study:

ICELAND • 5 syntypes; Northeast Atlantic, S Iceland, Medelland Bugt; 19 Jul. 1903; EtOH preserved; depth 70-90 fathoms (128-165 m); NHMD 658820.

The type material of the following species is probably lost or was never deposited (type localities in brackets): Sigalion limicola (Croatia, Quarnero, Adriatic Sea), Sthenelais leiolepis (Italy, Gulf of Naples, W Mediterranean Sea) and Sthenelais haddoni (off SW Ireland, Northeast Atlantic).

Other material (examined)

UNITED KINGDOM • 2 specs; NW Irish Sea; stn CEFNWIS04 154a; 28 Jul. 2004; EtOH preserved; TUM 37563 (Figs 1B-C, 2) • 1 spec.; Irish Sea, Liverpool Bay; stn CEFSZ07 Z02a; 19 Feb. 2008; EtOH preserved; TUM $43034 \cdot 3$ specs; S England, Hastings; stn CEFAY04 L6Ya; 30 Aug. 2004; EtOH preserved; TUM 33648.

Further Mediterranean material, see Barnich \& Fiege (2003). 


\section{Description}

Prostomium. Median antenna with long, smooth, tapering style; ceratophore with large auricles. Lateral antennae fused to inner dorsal side of tentaculophores, very short, not reaching half the length of the dorsal tentacular cirri. Two pairs of eyes present (Fig. 1A).

TENTACULOPHORES. Dorsal tentacular cirri shorter than median antenna, of similar shape. Ventral tentacular cirri shorter than dorsal ones (Fig. 1A).

ElytRA. Outer lateral margin with irregular extensions (anterior elytra) or notched (posterior elytra); surface smooth, except for some microtubercles near anterior margin (usually disappearing in posterior elytra) (Fig. 1B-C).

CIRRI. Dorsal cirri absent from segment 3. Ventral cirri without basal knob and without long basal papillae (Fig. 2A-B).

PARAPODIA. Stylodes without papillae, slender, cirriform. Parapodia of anterior body with stylodes present on anterior side of notopodial bract, on neuropodial acicular lobe and distally on upper and lower parts of large bilobed posterior bracts; number and length of distal stylodes decreasing along body. Margins of anterodorsal and anteroventral bracts smooth. Additional long, dorsal papillae on notopodia, a single papilla on anteriormost segments, up to 5 more posteriorly (Fig. 2A-B).

ChAETAE. Notochaetae slender, spinous, tapering to simple capillary tip. Upper neurochaetae slender compound spinigers with multi-articled blade; slender compound falcigers with multi-articled blade and
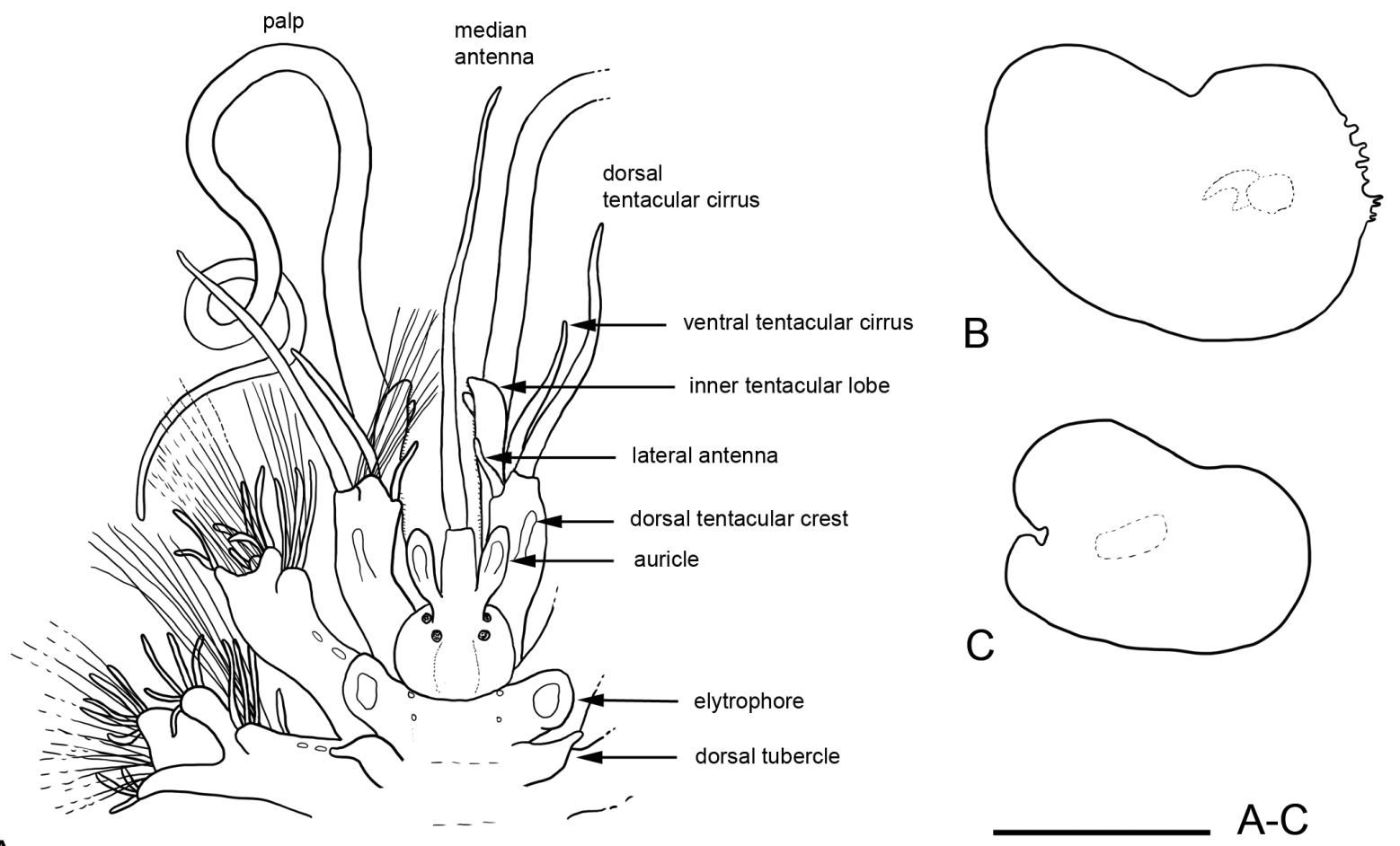

Fig. 1. Sthenelais limicola (Ehlers, 1864), modified from Pruvot \& Racovitza (1895) (A) and TUM 37563 (B-C). A. Anterior end, chaetae on right side of prostomium not figured. B. Right elytron of segment 7. C. Left elytron of posterior segment. Scale bar: $1 \mathrm{~mm}$. 
minutely bidentate tip; and few simple, spinous chaetae. Middle neurochaetae stout compound falcigers with short single- or bi-articled blade and bidentate tip. Lower neurochaetae slender compound falcigers with multi-articled blade and minutely bidentate tip (Fig. 2C-G).

SizE. Length up to $100 \mathrm{~mm}$, width up to $3 \mathrm{~mm}$ for 200 segments (see Chambers \& Muir 1997). Specimen figured, TUM 37563 (Figs 1B-C, 2): complete specimen, length $50 \mathrm{~mm}$, width $1.5 \mathrm{~mm}$ for 128 segments. Syntypes of $S$. filamentosus, NHMD 658820: 5 anterior fragments ranging in length from $10 \mathrm{~mm}$ to $25 \mathrm{~mm}$, width all about $3 \mathrm{~mm}$ for 23 to 52 segments.

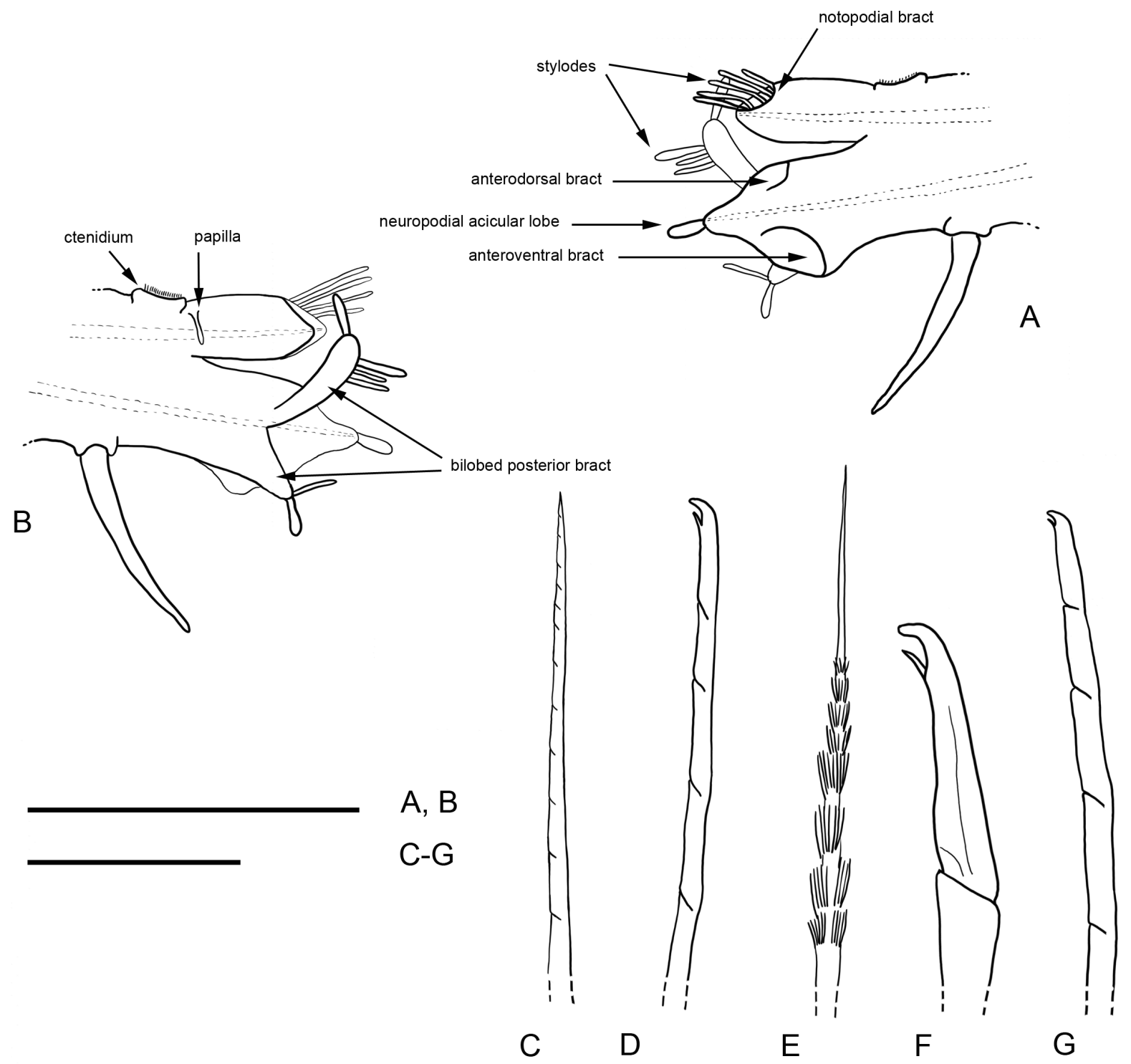

Fig. 2. Sthenelais limicola (Ehlers, 1864). TUM 37563. A. Right parapodium of segment 8; anterior view. B. Same, posterior view. C-G. Neurochaetae of segment 23, all distal part. C. Upper compound spiniger. D. Upper slender compound falciger. E. Upper simple, spinous neurochaeta. F. Middle stout compound falciger. G. Lower slender compound falciger. Scale bars: $A-B=500 \mu \mathrm{m} ; \mathrm{C}-\mathrm{G}=100 \mu \mathrm{m}$. 


\section{Remarks}

The description above is emended for the terminology used in describing the neuropodial bracts, for the presence of long, dorsal papillae on the notopodia and for the length and number of stylodes along the body: they are very long on segment 2 (some nearly reaching the length of the chaetae), becoming shorter on the following parapodia; this character led Ditlevsen (1917) to name his new species filamentosus.

The syntypes of $S$. filamentosus are in good condition and our examination revealed that they also show the other diagnostic characters of S. limicola as described above. Sthenelais limicola (Ehlers, 1864) predates S. filamentosus Ditlevsen, 1917, which becomes its junior synonym.

The type material of Sthenelais haddoni is probably lost; it consisted of a posterior fragment with completely smooth elytra presenting the typical lateral notch of S. limicola (see description in McIntosh 1897a). Sthenelais limicola has priority and S. haddoni becomes its junior synonym.

Compared to other species of the genus, Sthenelais limicola presents a number of remarkable characters:

The compound neurochaetae include not only falcigers, but also spinigers. The anteriormost segments of Sthenelais articulata Kinberg, 1856 also show some compound spinigers (see Pettibone 1971), but this type of chaetae was not listed as a diagnostic generic character by Pettibone or any subsequent workers. Compound spinigers in addition to falcigers are found in other sigalionid genera, for example in Eusthenelais hibernica, the type species of Eusthenelais (see below). However, this genus clearly differs by the presence of a pair of dorsal cirri on segment 3 .

The presence of additional long papillae dorsally on the notopodia is another remarkable character. So far, such papillae have not been described for any other species of Sthenelais. Similar papillae are found ventrally on the neuropodia of some, but not all, species of Willeysthenelais (see Pettibone 1971). All members of this genus are characterised by additional long papillae on the bases of the ventral cirri.

Consequently, these remarkable characters (presence of spinigers in addition to falcigers and long dorsal papillae on notopodia) might justify the erection of a new genus.

In their phylogenetic study of Aphroditiformia combining molecular and morphological data, Gonzalez et al. (2018) found that Sthenelais limicola formed a clade with Fimbriosthenelais longipinnis and Willeysthenelais diplocirrus (Grube, 1875), while Sthenelais boa formed a clade with Pholoides asperus (Johnson, 1897) and Pholoides dorsipapillatus (Marenzeller, 1893). This seems to confirm our opinion that the current generic assignment of Sigalion limicola should be reconsidered. A more detailed study combining molecular data of a larger number of Sthenelais species with the emended diagnostic characters described herein would be desirable to justify the erection of a new genus for Sigalion limicola. However, in a personal comment B. Gonzalez stated that there are currently not enough suitable specimens available to conduct a more detailed molecular study.

\section{Distribution and habitat}

Widely reported throughout the area. In the Northeast Atlantic present around the British Isles (RB data, based on TUM reference collection, and Chambers 1985), Northern and Central North Sea (RB and TvH data), in the Skagerrak, Kattegat and northern Öresund (Hartmann-Schröder 1996), along the French Atlantic coast (Fauvel 1923), and around the Iberian Peninsula (Núñez et al. 2015). In the Mediterranean Sea confirmed for the Western Mediterranean and the Adriatic Sea and reported from other areas (Barnich \& Fiege 2003). Also recorded from the Northwest and Southeast Atlantic; however, these records require confirmation. Occurring on muddy substrates at depths of 20 to $1550 \mathrm{~m}$. 
Sthenelais boa (Johnston, 1833) (emended)

Figs 3-4, 5A-D

Sigalion boa Johnston, 1833: 322, fig. 42.

Sigalion Idunae Rathke, 1843: 150-155, pl. 9 figs 1-8 (fide Malmgren 1866).

Sthenelais ctenolepis Claparède, 1868: 398, pl. 4 fig. 1a-k, pl. 6 fig. 2 (see Barnich \& Fiege 2003).

Sthenelais fuliginosa Claparède, 1868: 404, pl. 4 fig. 2a-h (see Barnich \& Fiege 2003).

Sthenelais minor Pruvot \& Racovitza, 1895: 465, pl. 20 figs 111-121. Syn. nov.

? Sigalion Estellae Guérin-Méneville, 1843: 2, pl. 1 fig. 1 (see Fauvel 1923; however, description insufficient).

?Sthenelais Audouinii Quatrefages, 1866: 275 (see Fauvel 1923; indeterminable according to Chambers \& Muir 1997, description by Quatrefages referring to Leanira or Sthenelais).

? Sthenelais Edwardsii Quatrefages, 1866: 273 (see Fauvel 1923; however, description insufficient).

? Sthenelais Leidyi Quatrefages, 1866: 278 (see Pettibone 1963; however, status questionable, see remark below).

Sthenelais boa-McIntosh 1900: 408, pl. 26 figs 7-8, pl. 26a fig. 21, pl. 29 fig. 1, pl. 31 fig. 5, pl. 33 fig. 16, pl. 34 fig. 6, pl. 41 figs 19-23. - Fauvel 1923: 110, fig. 41a-1. - Chambers 1985: 27, figs 2c, 12, 15a, 16a-c, 21a. - Hartmann-Schröder 1996: 81, fig. 27. — Chambers \& Muir 1997: 155, fig. 50. — Barnich \& Fiege 2003: 130, fig. 64. — Wehe 2007: 102, fig. 20. — Gil 2011: 946. — Núñez et al. 2015: 241, fig. 97.

Sthenelais minor? - Saint-Joseph 1899: 171 (specimen checked by Chambers \& Muir $1997=$ juvenile of Sthenelais boa).

Fimbriosthenelais minor - Pettibone 1971: 35-37, fig. 23. — Barnich \& Fiege 2003: 117-119, fig. 59. Gil 2011: 940. — Núñez et al. 2015: 221, fig. 89.

\section{Diagnosis}

Dorsal cirri absent on segment 3. Ventral body surface smooth. Outer elytral margin straight, with filiform papillae; elytral surface covered by conical microtubercles. Parapodial stylodes smooth (except for minute papillae in parapodia of juveniles or in anteriormost parapodia of adults), more or less clubshaped; notopodia without long dorsal papillae; margins of anterior neuropodial bracts with digitiform extensions. Notochaetae tapering to simple or minutely bidentate capillary tip.

Type material (examined)

UNITED KINGDOM • 2 syntypes; North Sea, Berwick Bay, Northeast England; EtOH preserved; BMNH 1921.12.16.1.

The type material of the following species is probably lost or has never been deposited (type localities in brackets): Sigalion Idunae (Norway, Molde, Northeast Atlantic), Sthenelais ctenolepis and Sthenelais fuliginosa (Italy, Gulf of Naples, W Mediterranean Sea), Sthenelais minor (France, near Banyuls, W Mediterranean Sea), Sigalion Estelloe and Sthenelais Audouinii (France, Northeast Atlantic), Sthenelais Edwardsii (France, Boulogne and St-Vaast, Northeast Atlantic), Sthenelais Leidyi (United States, New Jersey, NW Atlantic).

\section{Other material (examined)}

CROATIA - 1 spec.; central Mediterranean Sea, Adriatic Sea, Rovinj, near Banjole; stn ROV99-02; $45^{\circ} 5.47^{\prime} \mathrm{N}, 13^{\circ} 36.32^{\prime} \mathrm{E}$; depth $26 \mathrm{~m} ; 20$ Aug 1999; EtOH preserved; SMF 10598. (in Barnich \& Fiege 2003 as Fimbriosthenelais minor) 
FRANCE • 1 spec.; W Mediterranean Sea, Banyuls-sur-Mer; Posidonia beds; depth 5 m; 19 Mar 1997; EtOH preserved; SMF 10629. (Fig. 4C, F-I)

IRELAND - 3 specs; Irish Sea, Arklow Bank; stn ASUARK06 D06a; 5 Oct. 2006; EtOH preserved; TUM 39683. (Fig. 4A-B, D-E, 5A-D)

THE NETHERLANDS • 1 spec.; E Schelde estuary, Zandkreekdam; stn ZLOSZK4; $51.55^{\circ} \mathrm{N}, 3.88^{\circ}$ E; $1 \mathrm{~m}$ depth; 30 Jan. 2006; EtOH preserved; Eurofins TvH collection $335780 \bullet 1$ spec.; E Schelde estuary, Vondelingenplaat; stn ZLOSV5; $51.57^{\circ} \mathrm{N}, 3.94^{\circ} \mathrm{E}$; $1 \mathrm{~m}$ depth; 11 Feb. 2008; EtOH preserved; Eurofins TvH collection $351374 \bullet 1$ spec.; North Sea, artificial reef; stn 10-80 ZUID/NZKR1; $52.25^{\circ} \mathrm{N}, 4.29^{\circ} \mathrm{E}$; 18 m depth; 19 Oct. 1994; EtOH preserved; Eurofins TvH collection $10855 \cdot 1$ spec.; Voordelta, W of Westenschouwen; stn RefZRand_95; 51.68 N, 3.65 ${ }^{\circ}$ E; $17 \mathrm{~m}$ depth; 8 Oct. 2018; EtOH preserved; Eurofins TvH collection $429007 \cdot \overline{3}$ specs; Voordelta, N of Domburg; stn RefZuid $372 ; 51.64^{\circ} \mathrm{N}, 3.39^{\circ} \mathrm{E}$; 20 m depth; 14 Sep. 2018; EtOH preserved; Eurofins TvH collection $429132 \cdot \overline{4}$ specs; Voordelta, near Brouwersdam; stn BB_zra_168 rv01; $51.78^{\circ} \mathrm{N}, 3.85^{\circ}$ E; $4 \mathrm{~m}$ depth; 5 Sep. 2018; EtOH preserved; Eurofins TvH collection 429068 - 1 spec.; Voordelta, W of Visschershoek; stn BVO_614; $51.79^{\circ} \mathrm{N}$, 8.80 E; 3 m depth; 28 Sep. 2018; EtOH preserved; Eurofins TvH collection 429209.

UNITED KINGDOM • 1 spec.; S England, Portland Harbour; stn MBIPH0905 FDD1a; 2005; EtOH preserved; TUM 37130 - 1 spec.; Isle of Wight; stn CEFEIOW06 G12c; 2006; EtOH preserved; TUM 39122.

Further Mediterranean material see Barnich \& Fiege (2003).

\section{Description}

Prostomium. Median antenna with long, smooth, tapering style; ceratophore with large auricles. Lateral antennae fused to inner dorsal side of tentaculophores, very short, not reaching half the length of dorsal tentacular cirri. Two pairs of eyes present (Fig. 4A).

Tentaculophores. Dorsal tentacular cirri long, size and shape similar to median antenna. Ventral tentacular cirri slightly shorter than dorsal ones (Fig. 4A).

ELYTRA. With filiform and shorter, clavate papillae on outer lateral margin and surface covered by conical microtubercles (Fig. 4B-C).

CIRRI. Dorsal cirri absent from segment 3. Ventral cirri with basal knob but without long basal papillae.

PARAPODIA. Stylodes without papillae, more or less club-shaped (occasionally minute papillae present in parapodia of juveniles or in anteriormost parapodia of adults) (Fig. 5A-D). Parapodia of anterior and middle body with stylodes variably present on anterior side of notopodial bract, on neuropodial acicular lobe and on lower part of bilobed posterior neuropodial bract. Margins of neuropodial anterodorsal and anteroventral bracts with digitiform extensions. Without long dorsal papillae on notopodia (Figs 3, 4D-E).

ChAETAE. Notochaetae slender, spinous, tapering to simple or minutely bidentate capillary tip. Upper neurochaetae mainly slender compound falcigers with multi-articled blade and minutely bidentate tip and few simple, spinous chaetae. Middle neurochaetae stout compound falcigers with short singlearticled blade and bidentate tip. Lower neurochaetae slender compound falcigers with multi-articled blade and minutely bidentate tip (Fig. 4F-I).

Size. Length up to $200 \mathrm{~mm}$, width up to $10 \mathrm{~mm}$ for about 200 segments (see Chambers \& Muir 1997). Syntypes of Sigalion boa (BMNH 1921.12.16.1): 1 complete specimen, length about $170 \mathrm{~mm}$, width 
$7 \mathrm{~mm}$ for about 205 segments; 1 complete specimen, length about $140 \mathrm{~mm}$, width $7 \mathrm{~mm}$ for about 195 segments. Specimens figured: TUM 39683: anterior fragments: large specimen width $6 \mathrm{~mm}$ (Figs 4A-B, D-E, 5A-B); medium specimen width $4 \mathrm{~mm}$ (Fig. 5C), small specimen width $3 \mathrm{~mm}$ (Fig. 5D); SMF 10629: anterior fragment, width $3.5 \mathrm{~mm}$ (Fig. 4C, F-I).

\section{Remarks}

The description above is emended for the potential presence of minute papillae on the stylodes of anteriormost parapodia in adults (and in general in parapodia of juveniles) and for terminology used in description of the neuropodial bracts.

After examination of numerous specimens (see above), we agree with Chambers \& Muir (1997) that adult Sthenelais boa have smooth stylodes on the majority of parapodia, but can have minute papillae on the stylodes of some anterior parapodia. Also juveniles may have minutely papillated stylodes.

Chambers \& Muir (1997) checked Saint-Joseph's specimen of Sthenelais minor?, which was used by Pettibone (1971) for the description of Fimbriosthenelais minor, and concluded that this specimen is a juvenile of Sthenelais boa. Consequently, they listed Fimbriosthenelais minor sensu Pettibone as a synonym, but they did not include Sthenelais minor Pruvot \& Racovitza, 1895 in the synonymy.

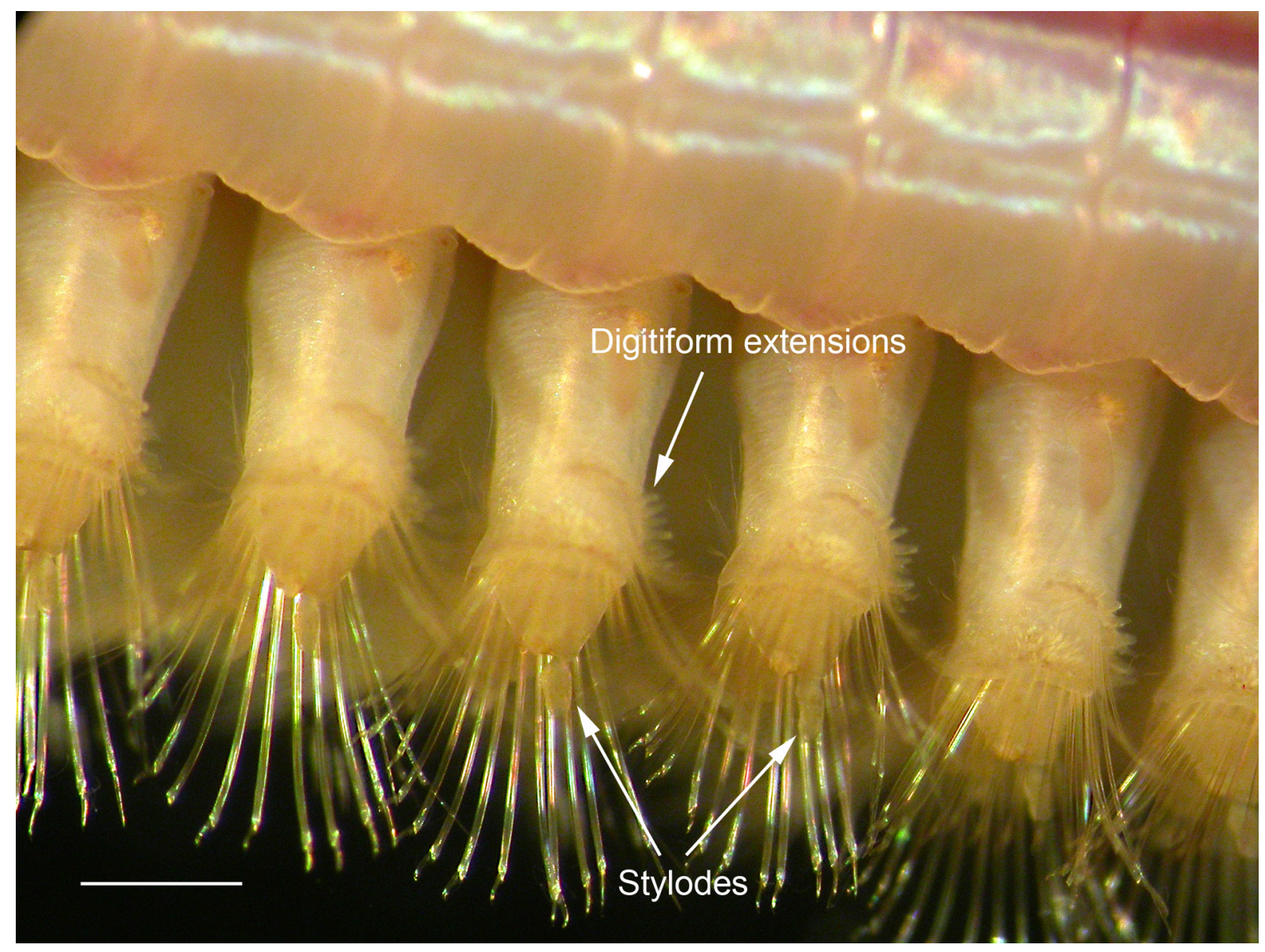

Fig. 3. Stylodes and digitiform extensions on parapodia of Sthenelais boa (Johnston, 1833), ventral view (photograph by D. Fiege, Senckenberg Museum). Scale bar: $250 \mu \mathrm{m}$. 

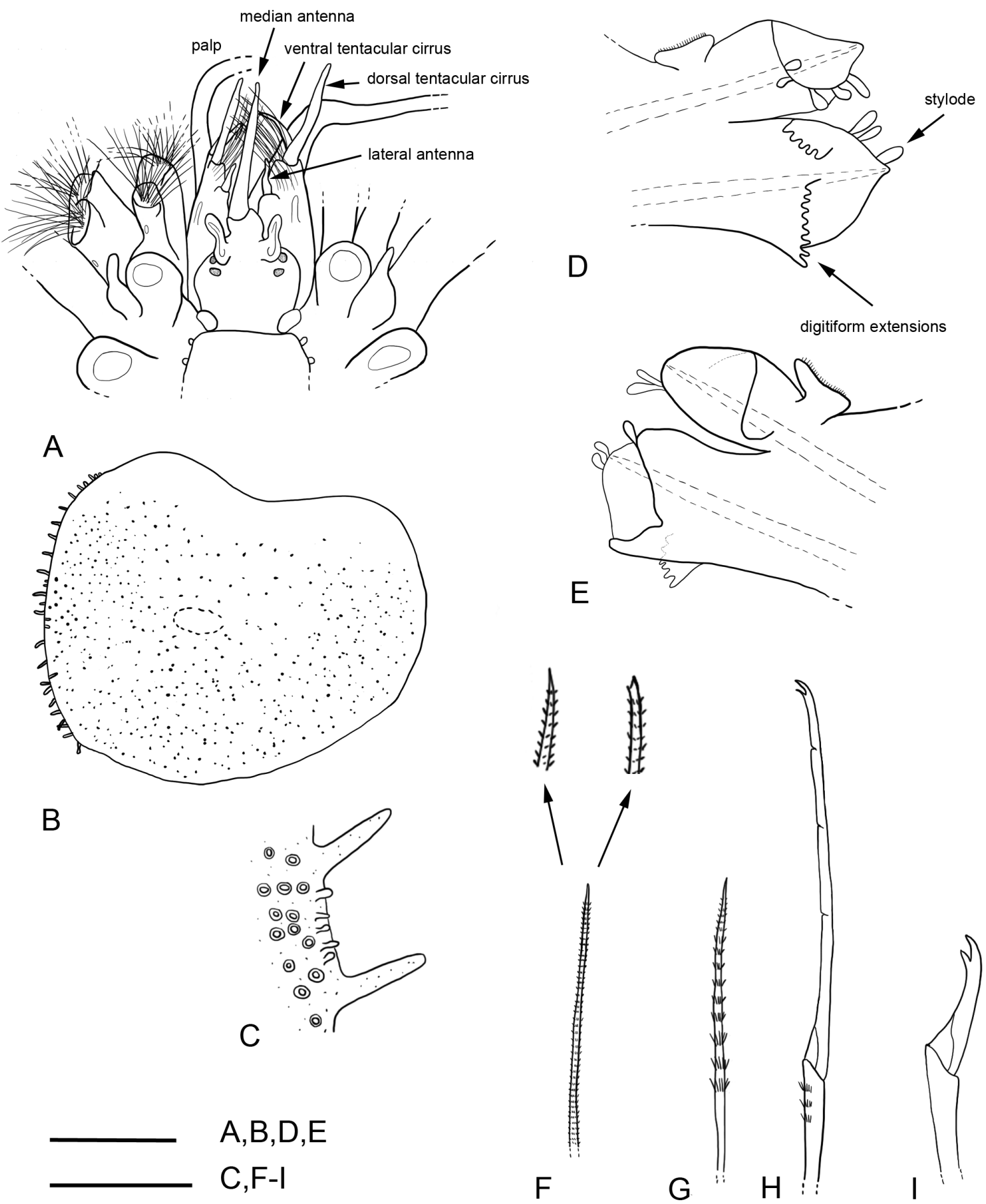

Fig. 4. Sthenelais boa (Johnston, 1833). TUM 39683 (A-B, D-E) and SMF 10629 (C, F-I). A. Anterior end. B. Left elytron of segment 21. C. Detail of outer lateral elytral margin. D. Left parapodium of segment 21, anterior view. E. Same, posterior view. F. Capillary notochaeta, with details of simple or bidentate tip (not to scale). G-I.Neurochaetae of segment 19, all distal part. G. Upper simple, spinous neurochaeta. H. Upper slender compound falciger. I. Middle stout compound falciger. Scale bars: $\mathrm{A}-\mathrm{B}=1 \mathrm{~mm} ; \mathrm{D}-\mathrm{E}=250 \mu \mathrm{m} ; \mathrm{C}, \mathrm{F}-\mathrm{I}=100 \mu \mathrm{m}$. 

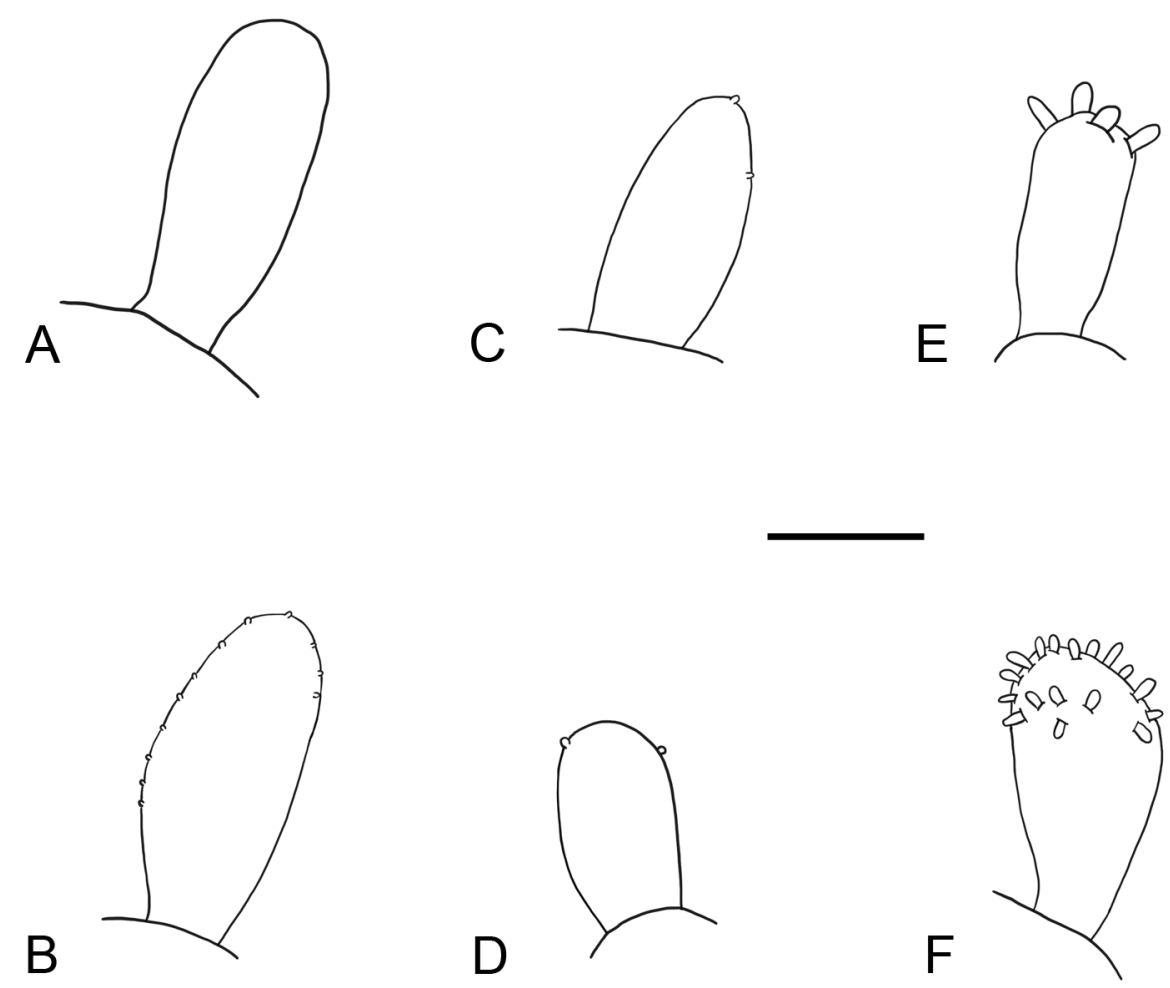

Fig. 5. Comparison of stylodes. A-D. Sthenelais boa (Johnston, 1833), TUM 39683. A. Large specimen, width $6 \mathrm{~mm}$, segment 21. B. Same, segment 4. C. Medium specimen, width $4 \mathrm{~mm}$, segment 21 . D. Small specimen, width $3 \mathrm{~mm}$, segment 21. E. Fimbriosthenelais longipinnis (Grube, 1869), SMF 24345, width $2.5 \mathrm{~mm}$, segment from mid-body. F. Fimbriosthenelais zetlandica (McIntosh, 1876), TUM 36747, width $4 \mathrm{~mm}$, segment 20. Scale bar: $50 \mu \mathrm{m}$.

Although the type material of Sthenelais minor is probably lost, the original description and figures clearly show the diagnostic characters of Sthenelais boa. We, therefore, confirm the synonymy of both species.

The presence of minute papillae on the stylodes of Sthenelais boa leaves us with a taxonomic dilemma regarding the validity of the genus Fimbriosthenelais. This has been discussed in the past by Barnich \& Fiege (2003) and Gil (2011). According to Pettibone (1971), the genus Fimbriosthenelais was established for species with papillated stylodes, while the stylodes of Sthenelais are smooth. Thus, we could agree with Chambers \& Muir (1997) and move all species of Fimbriosthenelais back into Sthenelais.

During this study, however, we noted that under moderate magnification (compound microscope $400 \times$ ) the papillae on the stylodes of Fimbriosthenelais longipinnis and F. zetlandica are much larger and more easily observed than on the stylodes of Sthenelais boa, where, if present at all, they are minute and difficult to see. To allow for a comparison of the sizes of these papillae, Fig. 5 presents stylodes of the different species drawn to the same scale.

For the time being, we suggest to emend the respective generic diagnoses and preserve the genus Fimbriosthenelais. Further studies, including also new species described after Pettibone's revision from 
other parts of the world and combining morphological and molecular data, would be helpful to support the validity of Fimbriosthenelais.

Sthenelais leidyi was a new name established by Quatrefages (1866) for Sigalion mathildae in Leidy (1855) [not Sigalion mathildae Audouin \& Milne-Edwards, 1832]. Pettibone (1963) listed S. leidyi as a synonym of $S$. boa in her study of polychaetes from New England (NW Atlantic). The head figured by Leidy (1855) possibly shows a Sthenelais, but the description is insufficient to attribute it to any known species. We therefore consider this synonymy questionable for the time being, as a revision of species and type material outside the Northeast Atlantic is beyond the scope of this paper.

In Chambers \& Muir (1997) Sigalion carringtonii Carrington, 1865 is listed as a synonym of Sthenelais boa without reference to examination of type material. Mackie \& Chambers (1990), however, investigated the syntypes of $S$. carringtonii and placed it in synonymy with Sigalion mathildae Audouin \& Milne Edwards, 1832; this view was already adopted earlier by McIntosh (1900) and Hartman (1959) and is followed herein.

\section{Distribution and habitat}

Widely reported throughout the area. In the Northeast Atlantic present around the British Isles (RB data, based on TUM reference collection, and Chambers 1985), in the Skagerrak (Hartmann-Schröder 1996), the southern North Sea (south of the Frisian Front) (TvH data), along the French Atlantic coast (Fauvel 1923) and around the Iberian Peninsula (Núñez et al. 2015). In the Mediterranean Sea present in the Western and Eastern Mediterranean, the Adriatic and the Aegean Sea (Barnich \& Fiege 2003). Also recorded from other areas in the Atlantic and Indo-Pacific; however, these records require confirmation. Occurring on various substrates from shallow waters to $200 \mathrm{~m}$ depth.

Genus Fimbriosthenelais Pettibone, 1971 (emended)

Table 1

Fimbriosthenelais Pettibone, 1971: 25 (type species Fimbriosthenelais longipinnis Grube, 1869; revised by Pettibone 1971).

\section{Diagnosis}

Body. Elongate, with numerous segments; mid-dorsum bordered by a few pairs of small ctenidia.

ElYTRA. Numerous, on segments 2, 4, 5, 7, continuing on alternate segments to 27, then on every segment to end of body. Dorsal tubercles on segments 3, 6, 8, continuing on alternate segments to 26 .

Prostomium. Rounded, fused to first segment. Median antenna inserted terminally, with stout, cylindrical ceratophore with lateral auricles and tapering style. Lateral antennae fused to inner dorsal sides of tentaculophores, without ceratophore, distinctly shorter than dorsal tentacular cirri. Paired palps encircled by palpal sheath emerging ventrally to tentaculophores.

TENTACUlophores. With single aciculum, a pair of tentacular cirri, two bundles of capillary chaetae, L-shaped inner tentacular lobe with ciliated ridge and fused to palpal sheath, and dorsal tentacular crest.

SEGMENT 2. With first pair of elytra, biramous parapodia and buccal cirri longer than following ventral cirri. Small ctenidia on lateral lips and medial to ventral cirri in anterior segments.

SEgment 3. With dorsal tubercles fused to posterior sides of elytrophores of segment 2. Dorsal cirri absent. 
Branchiae. Cirriform, absent on anteriormost segments.

DORSAL CIRRI. Absent from all segments.

Ventral CIRRI. Styles with basal knob, without long basal papillae.

PARAPODIA. Biramous, each with up to three cup-shaped ctenidia dorsal to notopodia, noto- and neuropodial acicular lobes with accessory bracts and distinctly papillated stylodes. Notopodial acicular lobes nearly completely encircled by a bract covering the basis of the notochaetae. Neuropodial acicular lobes posteriorly with a large bilobed or truncate bract and anteriorly with two smaller crescent-shaped bracts.

CHAETAE. Notochaetae slender, spinous, tapering to capillary tip. Neurochaetae mostly compound falcigers and, if present, a few simple spinous chaetae; stems of compound chaetae usually with a few rows of spines distally. Neurochaetae arranged in three groups: upper group of neurochaetae within anterodorsal bract: mainly slender compound falcigers and a few simple, spinous chaetae (may be missing). Middle group of neurochaetae within posterior bract: all stout compound falcigers. Lower group of neurochaetae within anteroventral bract: all slender compound falcigers.

\section{Remarks}

The generic diagnosis of Fimbriosthenelais is emended for the presence of distinct (large) papillae on the stylodes to allow for differentiation from Sthenelais (see remarks related to S. boa above).

Based on our study, Fimbriosthenelais currently comprises two valid species in the wider NE Atlantic: F. zetlandica (McIntosh, 1876), which is widely distributed in the area, and F. longipinnis (Grube, 1869), a mainly Indo-Pacific species, which is also found in the eastern parts of the Mediterranean Sea. As discussed above, we agree that F. minor (Pruvot \& Racovitza, 1895) is a junior synonym of Sthenelais boa (Johnston, 1833). A final decision on the validity of the genus Fimbriosthenelais would require a complete revision of all species, especially also additional species described since Pettibone's revision (see Aungtonya \& Eibye-Jacobsen 2018).

Fimbriosthenelais zetlandica (McIntosh, 1876) (emended)

Figs 5F, 6

Sthenelais? zetlandica McIntosh, 1876a: 390, pl. 70 figs 15-17.

Sthenelais atlantica McIntosh, 1876b: 405, pl. 72 figs 16-17.

Sthenelais Sarsi McIntosh, 1897b: 174, pl. 3 figs 1-5 (description sufficient; see also Pettibone 1971).

Sthenelais papillosa Day, 1960: 289, fig. 3e-j.

Sthenelais vachoni Rullier, 1964: 139, fig. 6.

Sthenelais zetlandica - McIntosh 1900: 414, pl. 30 fig. 14, pl. 34 fig.7, pl. 41 figs 24-26. - Chambers 1985: 26, fig. 20a-b. — Chambers \& Muir 1997: 160, fig. 52.

Fimbriosthenelais zetlandica - Pettibone 1971: 32, figs 21-22. — Barnich \& Fiege 2003: 119, fig. 60. Gil 2011: 941. — Núñez et al. 2015: 223, fig. 90.

\section{Diagnosis}

Dorsal cirri absent on segment 3. Ventral body surface densely papillated. Outer and posterior elytral margin with numerous short papillae, elytral surface covered by rounded to conical microtubercles. Parapodial stylodes distinctly papillated. Neuropodial posterior bracts truncate. 


\section{Type material}

The holotypes of Sthenelais? zetlandica and Sthenelais atlantica were investigated by Pettibone (1971) and Chambers (1985); all others by Pettibone (1971), except for Sthenelais sarsi (type material probably lost).

The respective type localities are: Sthenelais? zetlandica (United Kingdom, Shetland Islands, NE Atlantic), Sthenelais atlantica (United Kingdom, NE Atlantic), Sthenelais Sarsi (Norway, Hardanger Fjord, NE Atlantic), Sthenelais papillosa (South Africa, False Bay, Southeast Atlantic), Sthenelais vachoni (Cape Verde Islands, NE Atlantic).

Other material (examined)

FRANCE -4 specs; W Mediterranean Sea, Cortiou; stn D1; 1976; EtOH preserved; ex Coll. Bellan; SMF 12682. (Fig. 6C, F-H)

IRELAND - 1 spec.; Irish Sea Benthos; stn ISB05b; 30 Jul. 2006; EtOH preserved; TUM 39480. (Fig. 6A-B, D-E)

UNITED KINGDOM • 1 spec.; S England, E English Channel; stn 92a; 22 Aug. 2005; EtOH preserved; TUM 36747 (Fig. 5F) • 1 spec.; S England, E English Channel; stn 166a; 22 Aug. 2005; EtOH preserved; TUM 37011 - 4 specs; S England, E English Channel; stn 217a; 22 Aug. 2005; EtOH preserved; TUM 36765.

Further Mediterranean material, see Barnich \& Fiege (2003).

\section{Description}

Prostomium. Median antenna with short, smooth, tapering style; ceratophore with small auricles. Lateral antennae fused to inner dorsal side of tentaculophores, very short, not reaching half the length of dorsal tentacular cirri. Two pairs of eyes present (Fig. 6A).

TENTACUlophores. Dorsal tentacular cirri subequal or slightly longer than median antenna, of similar shape. Ventral tentacular cirri about half the length of dorsal ones (Fig. 6A).

ELYTRA. With short, clavate papillae on outer lateral and posterior margin; surface covered by rounded to conical microtubercles (Fig. 6B-C).

CIRRI. Dorsal cirri absent from segment 3. Ventral cirri with basal knob and distal article, without long basal papillae (Fig. 6D-E).

PARAPODIA. Stylodes club-shaped or cylindrical, with large, obvious papillae (Fig. 5F). Parapodia of anterior and middle body with stylodes present on anterior side of notopodial bract, on neuropodial acicular lobe, on truncate posterior neuropodial bract, and on neuropodial anterodorsal and anteroventral bracts (Fig. 6D-E).

CHAETAE. Notochaetae slender, spinous, tapering to simple capillary tip. All neurochaetae compound falcigers with bidentate tip. Those of anteriormost segments slender with multi-articled blades. In all other parapodia falcigers of similar size and shape with bi- or three-articled blades. Middle neurochaetae slightly stouter than those of upper and lower groups (Fig. 6F-H).

BODY SURFACE. Densely papillated ventrally. 

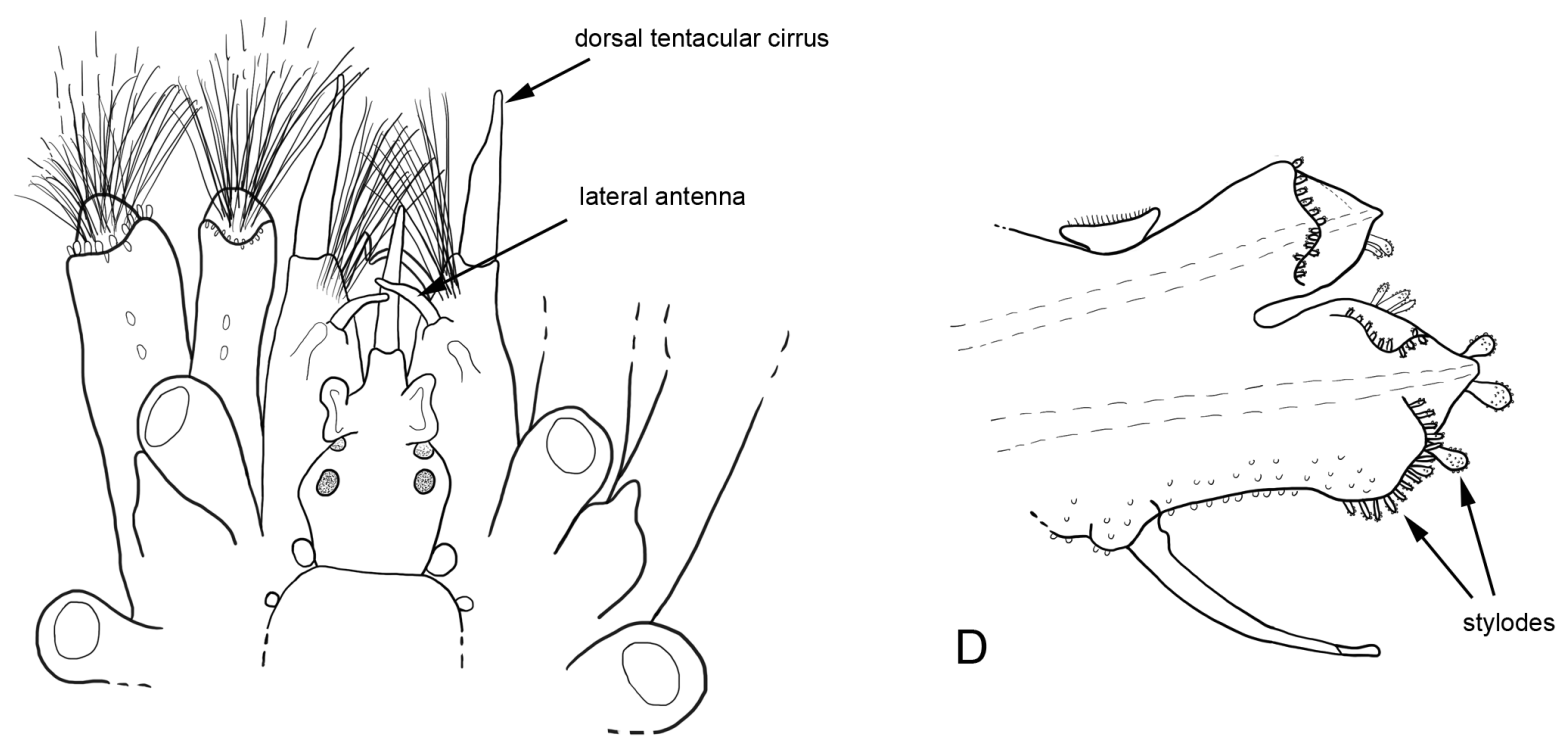

A

B
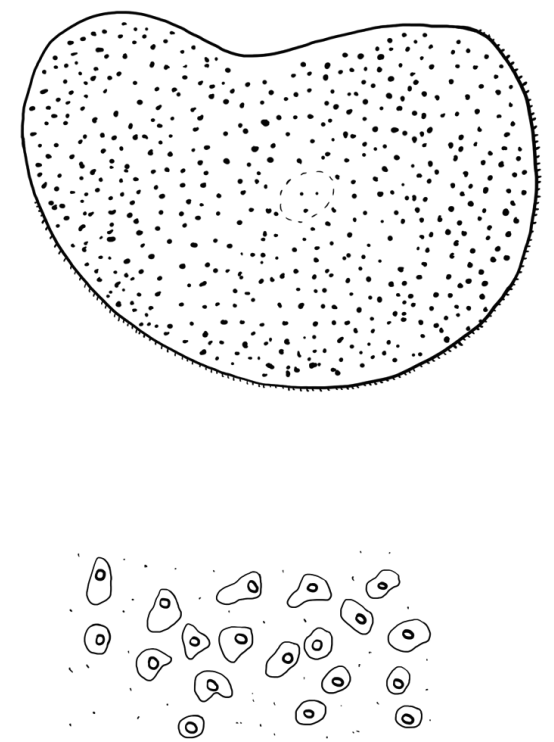

vorino

C
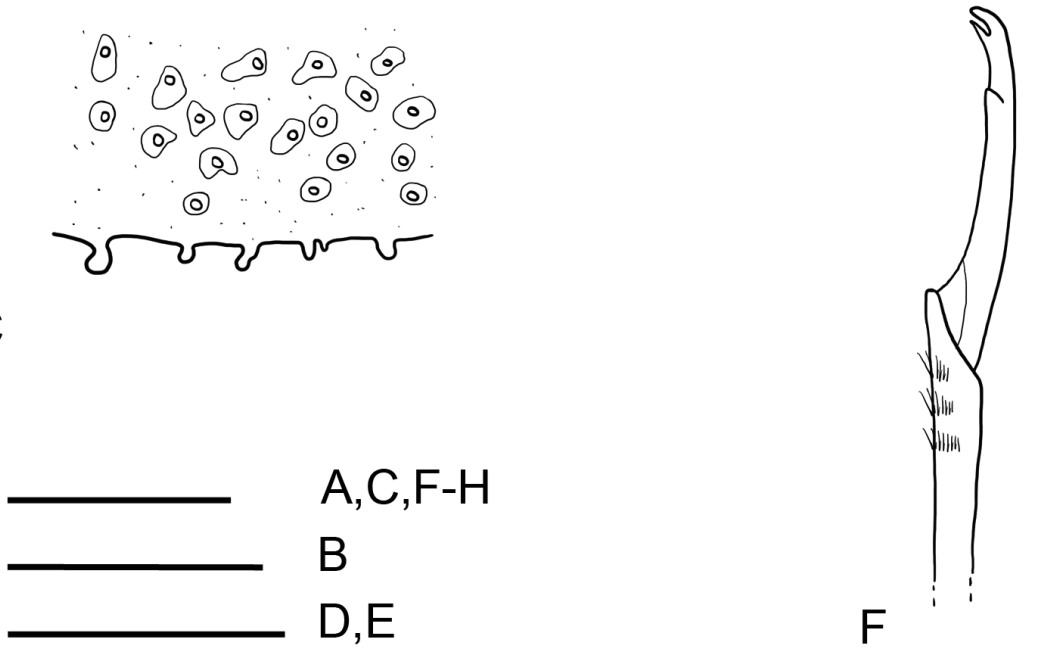

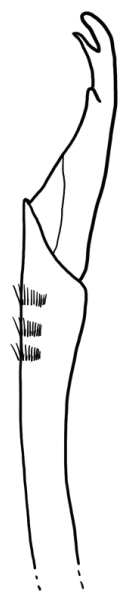

G

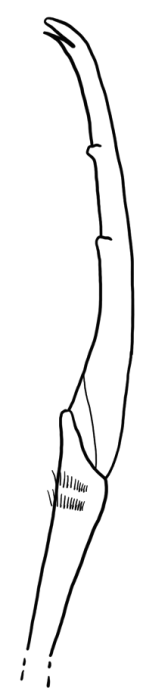

$\mathrm{H}$

Fig. 6. Fimbriosthenelais zetlandica (McIntosh, 1876). TUM 39480 (A-B, D-E) and SMF 12682 (C, F-H). A. Anterior end, palps not figured, bent downwards. B. Right elytron of segment 5. C. Detail of posterior elytral margin. D. Left parapodium of segment 13, anterior view. E. Same, posterior view. F-H. Neurochaetae of segment 11, all distal part. F. Upper compound falciger. G. Middle compound falciger. H. Lower compound falciger. Scale bars: A, D-E $=500 \mu \mathrm{m} ; \mathrm{B}=1 \mathrm{~mm} ; \mathrm{C}, \mathrm{F}-\mathrm{H}=100 \mu \mathrm{m}$. 
SizE. Length more than $40 \mathrm{~mm}$, width up to $4 \mathrm{~mm}$ for more than 100 segments. Specimens figured: TUM 36747 (Fig. 5F): anterior fragment, width 4 mm; TUM 39480 (Fig. 6A-B, D-E): complete specimen, length $54 \mathrm{~mm}$, width $3.5 \mathrm{~mm}$ for 120 segments; SMF 12682 (Fig. 6C, F-H): anterior fragment, width $4 \mathrm{~mm}$.

\section{Remarks}

The description above is emended for the details regarding shape and size of the stylodes and their associated papillae and for the terminology used in the description of the neuropodial bracts.

\section{Distribution and habitat}

Reported from the NE and Southeast Atlantic and the Mediterranean Sea. Also reported from the Gulf of Oman, Indian Ocean. Occurring on muddy substrates from 30 to $560 \mathrm{~m}$ depth (see Pettibone 1971; Barnich \& Fiege 2003; Wehe 2007).

Fimbriosthenelais longipinnis (Grube, 1869) (emended)

Figs 5E, 7

Sthenelais longipinnis Grube, 1869: 493.

Sthenelais variabilis Potts, 1910: 349, pl. 19 fig. 22, pl. 21 fig. 63 [part; var. glabra].

Sthenelais dubiosa Horst, 1917: 111, pl. 22 fig. 7.

Fimbriosthenelais longipinnis - Pettibone 1971: 26, figs 15-17. — Aungtonya 2002: 217, figs 7-8. Barnich \& Fiege 2003: 117, fig. 58. — Wehe 2007: 64, fig. 5. — Gil 2011: 940 (?part, see remark below). - Aungtonya \& Eibye-Jacobsen 2018: 3, figs 1-2.

\section{Diagnosis}

Dorsal cirri absent on segment 3. Ventral body surface finely papillated. Outer elytral margin with filiform papillae, elytral surface with rounded to conical microtubercles (in anterior elytra surface completely covered, in middle and posterior elytra microtubercles confined to areas near margins). Neuropodial posterior bracts bilobed. Parapodial stylodes distinctly papillated.

\section{Type material}

The holotype of Sthenelais longipinnis was investigated by Pettibone (1971) and Wehe (2007), all others by Pettibone (1971).

The respective type localities are: Sthenelais longipinnis (Red Sea), S. variabilis (Maldive Islands, Hulule, Male Atoll, Indian Ocean), S. dubiosa (Indonesia, Indo-Pacific, several localities: Bay of Badjo, W Flores; Kwandang Bay; E of Dangar Besar, Saleh Bay).

Other material (examined)

CYPRUS - 3 specs; E Mediterranean Sea, Akrotiri Bay; stn CY08 SB76B; depth 55 m; 13 Feb. 1968; EtOH preserved; SMF 10597. (Fig. 7; see also Barnich \& Fiege 2003)

JORDAN - 1 spec.; Red Sea, Gulf of Aqaba, in front of Marine Science Station; on corals and stones; 8-10 m depth; 23 Mar. 2007; EtOH preserved; SMF 19366 (original identification by T. Wehe) • 1 spec.; Red Sea, Gulf of Aqaba, in front of Marine Science Station; in sea grass meadow; $22.5 \mathrm{~m}$ depth; 25 Mar. 2007; EtOH preserved; SMF 19394 (original identification by T. Wehe). 
SAUDI ARABIA - 1 spec.; Red Sea, Farasan Islands, Rabigh, coast guard station; stn RSS1 2011-1; 22 ${ }^{\circ} 58^{\prime} \mathrm{N}, 38^{\circ} 50^{\prime} \mathrm{E}$; 3-4 m depth; 7 Apr. 2011; EtOH preserved; SMF 24345 (see also Wehe 2017). (Fig. 5E)

\section{Description}

Prostomium. Median antenna with moderately long, smooth, tapering style; ceratophore with large auricles. Lateral antennae fused to inner dorsal side of tentaculophores, very short, not reaching half the length of dorsal tentacular cirri. Two pairs of eyes present.

TENTACULOPHORES. Dorsal tentacular cirri longer than median antenna, of similar shape. Ventral tentacular cirri about half the length of dorsal ones.

ELYTRA. With filiform and shorter, clavate papillae on outer lateral margin; surface of anterior elytra completely covered by rounded to conical microtubercles, in more posterior elytra microtubercles confined to areas near margins (Fig. 7A-B).

CIRRI. Dorsal cirri absent from segment 3. Ventral cirri with basal knob, without long basal papillae.

PARAPODIA. Stylodes more or less club-shaped, with large, obvious papillae (Fig. 5E). Parapodia of anterior and middle body with stylodes present on anterior side of notopodial bract, on neuropodial acicular lobe and on upper and lower parts of bilobed posterior neuropodial bract. Margins of neuropodial anteroventral bract with digitiform extensions, anterodorsal bract reduced, without stylodes or extensions (Fig. 7C).

ChAetAe. Notochaetae slender, spinous, tapering to simple capillary tip. Upper neurochaetae mainly slender compound falcigers with multi-articled blade and minutely bidentate tip and a few simple, spinous chaetae. Middle neurochaetae stout compound falcigers with short single- or up to three-articled blade and bidentate tip. Lower neurochaetae slender compound falcigers with multi-articled blade and minutely bidentate tip.

BODY SURFACE. Usually finely papillated ventrally.

SizE. Length more than $30 \mathrm{~mm}$, width up to $5 \mathrm{~mm}$ for more than 80 segments (see Pettibone 1971). Specimens figured: SMF 24345 (Fig. 5E): complete specimen, strongly coiled, length and number of segments not determined, width $2.5 \mathrm{~mm}$; SMF 10597 (Fig. 7): anterior fragment, width $2 \mathrm{~mm}$ for 23 segments.

\section{Remarks}

The description above is emended for the details regarding the shape and size of the stylodes and their associated papillae and for the terminology used in the description of the neuropodial bracts. The species has been extensively studied by Pettibone (1971), Wehe (2007) and Aungtonya \& Eibye-Jacobsen (2018); please refer to these works for additional details.

Specimens from the Western Mediterranean described by Gil (2011) seem to agree with F. longipinnis as described by Pettibone (1971) regarding their elytral characters and the finely papillated ventral body surface. However, they seem to differ due to a reduced number of stylodes (and those present having no papillae, but just sensorial hairs) and blades of falcigers with not more than three articles. Because of the confusing terminology regarding extensions and papillae on bracts, lobes and stylodes (see above), it is likely that the stylodes described by Gil (2011) as lacking papillae and having just hairs correspond to the extensions of the anteroventral bract. As mentioned by Pettibone (1971) the number of articles of the blades is rather variable and would also fit the current concept of $F$. longipinnis. Another possibility 
is that the specimens are juveniles of either F. longipinnis or maybe F. zetlandica. Unfortunately, those animals were not available for study and thus we cannot confirm the presence of this species in the Western Mediterranean.

The specimens of $F$. longipinnis from Cyprus (Eastern Mediterranean), described by Barnich \& Fiege (2003) and re-investigated herein, agree in all characters with Pettibone's revised description.

Sthenelais minor var. digitata Fauvel, 1919 was considered a possible synonym of F. longipinnis by Pettibone (1971). At the time of her revision no type material was available, but Wehe (2007) was able to examine the holotype and placed Sthenelais minor var. digitata in synonymy with Fimbriosthenelais hirsuta (Potts, 1910).

\section{Distribution and habitat}

Not known to occur in the Northeast Atlantic; presence confirmed for the Eastern Mediterranean Sea. Otherwise widely reported from the Red Sea and Indo-Pacific. Type of habitat unknown; in shallow water down to $75 \mathrm{~m}$ depth (see Pettibone 1971; Barnich \& Fiege 2003).

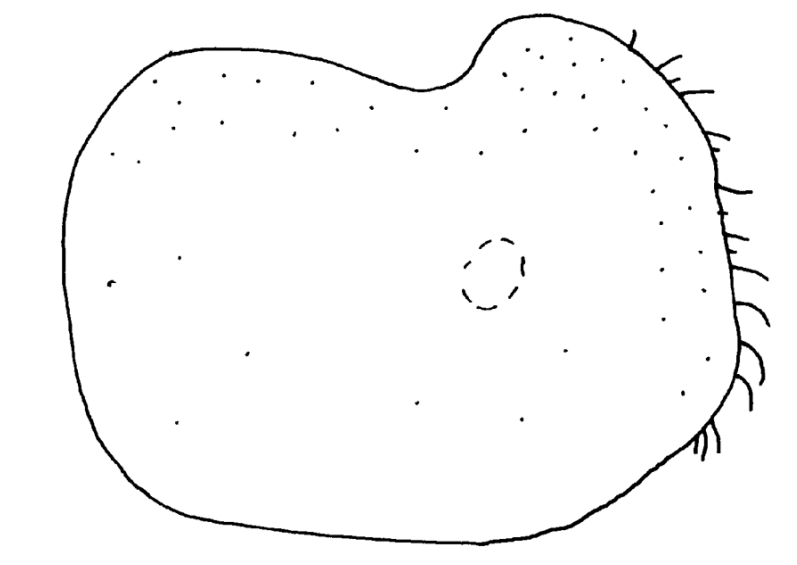

A

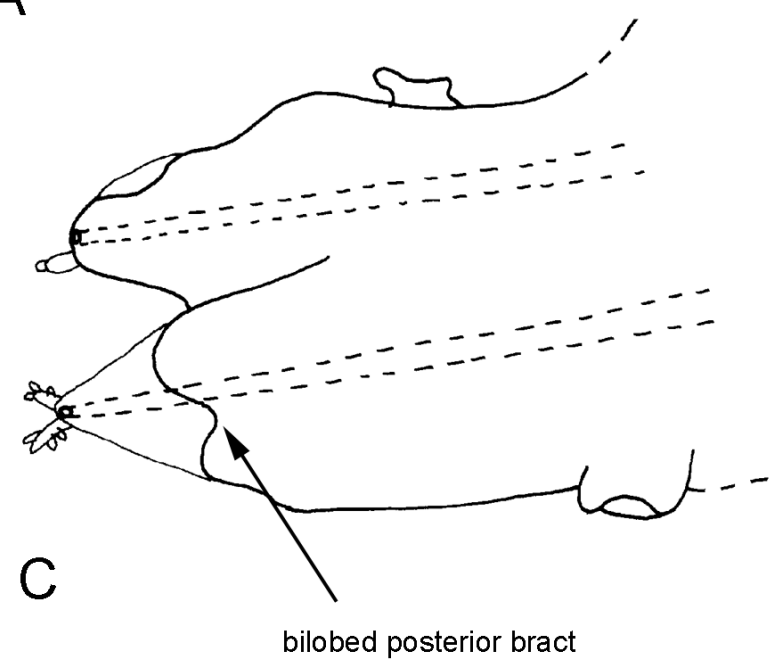

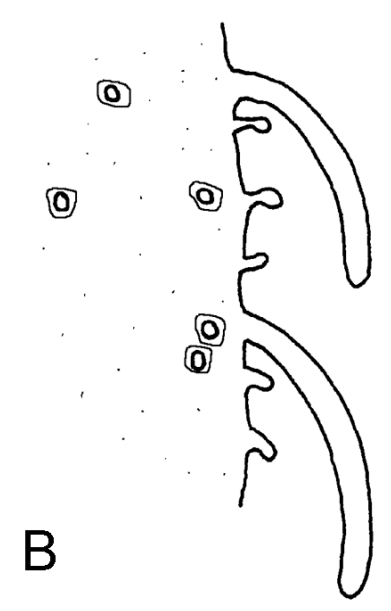

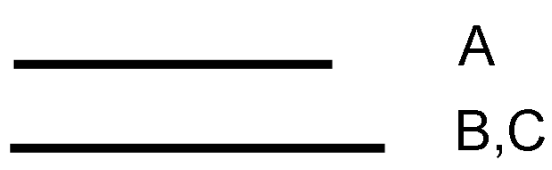

Fig. 7. Fimbriosthenelais longipinnis (Grube, 1869). SMF 10597. A. Right elytron of segment 11. B. Outer lateral margin of same. C. Left parapodium of segment 10, posterior view. Scale bars: $\mathrm{A}=500 \mu \mathrm{m} ; \mathrm{B}=100 \mu \mathrm{m} ; \mathrm{C}=250 \mu \mathrm{m}$. 
Genus Eusthenelais McIntosh, 1876 (emended)

Table 1

Eusthenelais McIntosh, 1876b: 407 (type species Eusthenelais hibernica McIntosh, 1876).

Parasthenelais Amoureux, 1972: 68 (type species Eusthenelais hibernica McIntosh, 1876; unjustified name change, see remark below).

\section{Diagnosis}

Body. Elongate, with numerous segments; mid-dorsum bordered by a few pairs of small ctenidia.

ELYTRA. Numerous, on segments 2, 4, 5, 7, continuing on alternate segments to 27, then on every segment to end of body. Dorsal tubercles on segments 3, 6, 8, continuing on alternate segments to 26 .

Prostomium. Rounded, fused to first segment. Median antenna inserted terminally, with stout, cylindrical ceratophore with lateral auricles and tapering style. Lateral antennae fused to inner dorsal sides of tentaculophores, without ceratophore, length equal to that of dorsal tentacular cirri. Paired palps encircled by palpal sheath emerging ventrally to tentaculophores.

TENTACULOPHORES. With single aciculum, a pair of tentacular cirri, two bundles of capillary chaetae, L-shaped inner tentacular lobe with ciliated ridge and fused to palpal sheath, and dorsal tentacular crest.

SEGMENT 2. With first pair of elytra, biramous parapodia and buccal cirri longer than following ventral cirri. Small ctenidia on lateral lips and medial to ventral cirri in anterior segments.

Segment 3. With dorsal tubercles, not fused to posterior sides of elytrophores of segment 2. Pair of dorsal cirri present.

BRANCHIAE. Cirriform, absent in anteriormost segments.

DORSAL CIRRI. Absent, except for segment 3.

VENTRAL CIRRI. Styles without basal knob or long basal papillae.

PARAPODIA. Biramous, each with up to three cup-shaped ctenidia dorsal to notopodia, noto- and neuropodial acicular lobes with accessory bracts and smooth stylodes. Notopodial acicular lobes nearly completely encircled by bract covering the basis of the notochaetae. Neuropodial acicular lobes posteriorly with large bilobed bract, anteriorly with two smaller crescent-shaped bracts.

ChAETAE. Notochaetae slender, spinous, tapering to capillary tip. Neurochaetae compound falcigers and spinigers; stems of compound chaetae usually with a few rows of spines distally. Neurochaetae arranged in three groups: upper group of neurochaetae within anterodorsal bract: all slender compound spinigers. Middle group of neurochaetae within posterior bract: compound spinigers and stout compound falcigers. Lower group of neurochaetae within anteroventral bract: all slender compound falcigers.

\section{Remarks}

Núñez et al. (2015) were the first to present an extended generic diagnosis for Eusthenelais. Their diagnosis is emended herein for the terminology used in the description of the parapodial bracts and stylodes, for characters describing the tentaculophores and the location of the different neurochaetae.

McIntosh established the genus Eusthenelais for specimens of E. hibernica differing from Sthenelais by the presence of compound spinigers in addition to bidentate falcigers (McIntosh 1876b, 1879, 1900). In 
the original description (McIntosh 1876b), he did not mention the presence of dorsal cirri on segment 3, but he refers to this character in the text and figures of his re-description of the same material (McIntosh 1900). The presence of dorsal cirri on segment 3 is of generic relevance and puts Eusthenelais closer to Neoleanira Pettibone, 1970 and clearly differentiates it from Sthenelais and Fimbriosthenelais, which lack any dorsal cirri. Neoleanira on the other hand differs from Eusthenelais by the absence of any bidentate falcigers, all neurochaetae being compound spinigers (see Pettibone 1970).

We agree with Wehe (2007), Gil (2011) and Aungtonya \& Eibye-Jacobsen (2014) that the generic name Parasthenelais Amoureux, 1972 is invalid. Amoureux (1972) redescribed the species Eusthenelais hibernica based on specimens collected in deep waters off the Galician coast and established a new generic name without valid reason.

Currently, Eusthenelais hibernica is the only valid representative of Eusthenelais. Another species assigned to the genus, Eusthenelais abyssicola McIntosh, 1879, was described for specimens from deep waters in the Davis Strait. However, we checked the holotype (BMNH 1921.5.1.622) which is unidentifiable. The description also being insufficient, we agree with Hartman (1965) and consider this to be an indeterminable sigalionid.

Eusthenelais hibernica McIntosh, 1876 (emended)

Fig. 8

Eusthenelais hibernica McIntosh, 1876b: 407, pl. 73, figs 4-5.

Sthenelais jeffreysi McIntosh, 1876b: 406, pl. 72 fig. 18, pl. 73 figs 1-2 (synonymy according to Eliason 1962, confirmed herein).

Sthenelais heterochaeta McIntosh, 1897b: 176, pl. 3 figs 6-10 (synonymy acc. to Eliason 1962, confirmed herein).

Eusthenelais hibernica - McIntosh 1900: 425, pl. 29 fig. 5, pl. 31 fig. 9, pl. 42 figs 9-10. — Gil 2011: 937. - Núñez et al. 2015: 233, fig. 93.

Sthenelais Jeffreysii - McIntosh 1900: 421, pl. 29 fig. 4, pl. 31 fig. 7, pl. 34 fig. 13, pl. 42 figs 5-8. — Gil 2011: 947.

Sthenelais jeffreysi - Eliason 1962: 224 fig. 5b-h.

Parasthenelais hibernica - Amoureux 1972: 68, fig. 1. — Barnich \& Fiege 2003: 11.

\section{Diagnosis}

Dorsal cirri present on segment 3. Ventral body surface and parapodial stylodes smooth. Outer elytral margin with several filiform papillae, elytral surface smooth. Neurochaetae spinigers and falcigers.

Type material (examined)

Eusthenelais hibernica:

IRELAND - syntype; NE Atlantic, W coast of Ireland; depth 106 fathoms (194 m); "Porcupine" expedition leg.; EtOH preserved; BMNH 1921.5.1.620.

PORTUGAL • syntype; off Cape Sagres; depth 45 fathoms (82 m); "Porcupine" expedition leg.; EtOH preserved; BMNH 1921.5.1.621.

Sthenelais jeffreysi:

IRELAND • holotype; NE Atlantic, W coast of Ireland, station 9; $53^{\circ} 16^{\prime} \mathrm{N}, 12^{\circ} 42^{\prime} \mathrm{W}$; depth 165 fathoms (302 m); 1869; "Porcupine" expedition leg.; EtOH preserved; BMNH 1921.5.1.616. 
The syntypes of Sthenelais heterochaeta (type locality: Norway, Osterfjorden, NE Atlantic) are probably lost.

Other material (examined)

UNITED KINGDOM - 1 spec.; NW Scotland, Geikie Slide and Hebridean Slope; stn C05 S41 A1; $58.38^{\circ} \mathrm{N}, 9.40^{\circ} \mathrm{W}$; depth $650 \mathrm{~m} ; 23 \mathrm{Jul}$. 2016; sandy mud; EtOH preserved; survey code JNCC/MSS 1016S GSH; TUM 65469 - 1 spec.; same locality as for preceding; stn C11 S15 A1; 58.45 N, 9.32 $\mathrm{W}$; depth $868 \mathrm{~m}$; $21 \mathrm{Jul}$. 2016; coarse sandy mud; EtOH preserved; ex TUM 65481; survey code JNCC/MSS 1016S GSH; NMS.Z. 2020.14.4 • 1 spec.; same locality as for preceding; stn D03 S83 A1; 58.29 $\mathrm{N}, 9.30^{\circ} \mathrm{W}$; depth $438 \mathrm{~m}$; 29 Jul. 2016; sandy mud; EtOH preserved; ex TUM 65499; survey code JNCC/MSS 1016S GSH; NMS.Z.2020.14.1 • 1 spec.; same locality as for preceding; stn D11 S61 A1; 58.40 N, 9.17 ${ }^{\circ} \mathrm{W}$; depth 496 m; 25 Jul. 2016; sandy mud; EtOH preserved; ex TUM 65515; survey code JNCC/MSS 1016S GSH; NMS.Z. 2020.14.3 • 1 spec.; same locality as for preceding; stn F04 S90 A1; $58.47^{\circ} \mathrm{N}, 8.78^{\circ} \mathrm{W}$; depth $410 \mathrm{~m}$; 29 Jul. 2016; sandy mud; EtOH preserved; ex TUM 65547; survey code JNCC/MSS 1016S GSH; NMS.Z. 2020.14.2 • 1 spec.; same locality as for preceding; stn F16 S75 A1; $58.59^{\circ} \mathrm{N}, 8.45^{\circ} \mathrm{W}$; depth $450 \mathrm{~m}$; 28 Jul. 2016; sandy mud; EtOH preserved; ex TUM 65571; survey code JNCC/MSS 1016S GSH; NMS.Z. 2020.14.5. (Fig. 8)

\section{Description}

Prostomium. Median antenna with long, smooth, tapering style; ceratophore with small auricles. Lateral antennae fused to inner side of tentaculophores, size and shape similar to dorsal tentacular cirri. Eyes indistinct (Fig. 8A).

TentACulophores. Dorsal tentacular cirri long, size and shape similar to median antenna. Ventral tentacular cirri short, not reaching half the length of the dorsal ones (Fig. 8A).

ELYTRA. With filiform papillae on outer lateral margin and smooth surface (Fig. 8B).

CIRRI. Dorsal cirri present on segment 3, size and shape similar to dorsal tentacular cirri. Ventral cirri without basal knob or long basal papillae (Fig. 8C-D).

PARAPODIA. Stylodes without papillae, slender, cirriform, some slightly inflated basally. Parapodia of anterior and middle body with few stylodes present along notopodial bract, on neuropodial acicular lobe and on upper and lower parts of large, bilobed posterior neuropodial bract. Margins of neuropodial anterodorsal and anteroventral bracts smooth. Without long dorsal papillae on notopodia (Fig. 8C-D).

ChAETAE. Notochaetae slender, spinous, tapering to simple capillary tip. Upper neurochaetae all slender compound spinigers. Middle neurochaetae slender compound spinigers and stout compound falcigers with short, 1-4 articled blade and bidentate tip. Lower neurochaetae slender compound falcigers with multi-articled blade and minutely bidentate tip (Fig. 8E-G).

SizE. Specimen figured: NMS.Z. 2020.14.5 (Fig. 8): anterior fragment, length $45 \mathrm{~mm}$, width $5 \mathrm{~mm}$ for 98 segments. Syntypes of Eusthenelais hibernica: BMNH 1921.5.1.620, anterior fragment, length $11 \mathrm{~mm}$, width $2.5 \mathrm{~mm}$ for about 28 segments; BMNH 1921.5.1.621, anterior and middle fragment, total length about $17 \mathrm{~mm}$, width $3.5 \mathrm{~mm}$ for 31 segments (total). Holotype of Sthenelais jeffreysi: BMNH 1921.5.1.616, anterior fragment, length $18 \mathrm{~mm}$, width $3 \mathrm{~mm}$ for about 39 segments.

\section{Remarks}

The description above is emended for the terminology used in describing the parapodial bracts and stylodes and the details regarding the shape and location of the neurochaetae. The recently collected specimens of 


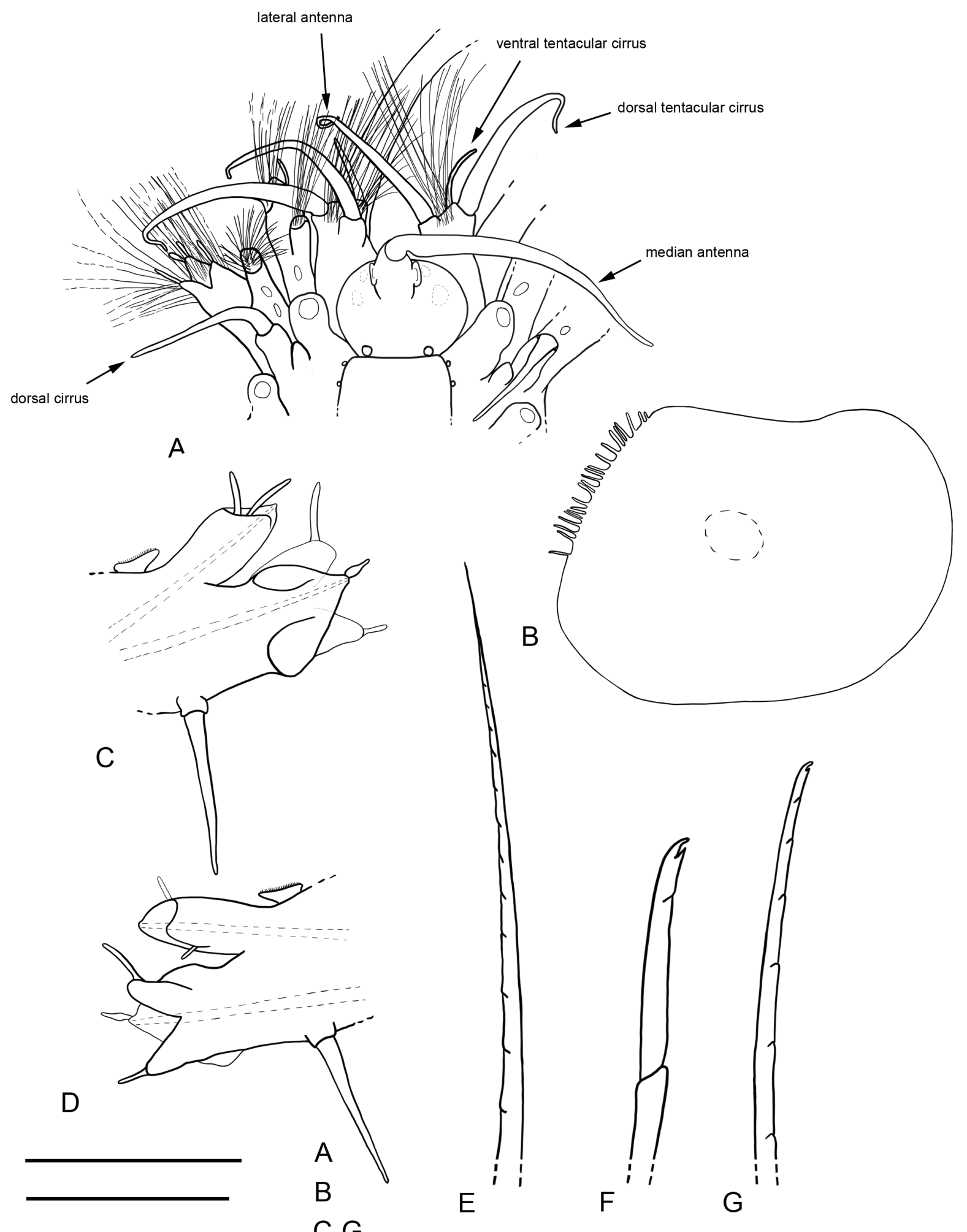

Fig. 8. Eusthenelais hibernica McIntosh, 1876. TUM 65571. A. Anterior end, left palp not figured, bent downwards. B. Left elytron of segment 17. C. Left parapodium of segment 19, anterior view. D. Same, posterior view. E-G. Neurochaetae of same, all distal part. E. Upper compound spiniger. F. Middle stout compound falciger. G. Lower slender compound falciger. Scale bars: $A=2 \mathrm{~mm}$; $B-D=1 \mathrm{~mm}$; $\mathrm{E}-\mathrm{G}=100 \mu \mathrm{m}$. 
E. hibernica from the Geikie Slide (Northwest Scotland) were in rather good condition and proved very helpful in supplementing the diagnostic characters of the species.

Chambers (1985) noted that the type material of Eusthenelais hibernica is unidentifiable and, consequently, Read \& Fauchald (2020) list Eusthenelais McIntosh, 1876 as a nomen dubium in WoRMS. However, especially the presence of both spinigers and bidentate falcigers as described by McIntosh (1876b) is sufficient to distinguish it from other sigalionid species. The other important generic character, i.e., the presence of dorsal cirri on segment 3 , was not mentioned in the original description, but later described by McIntosh (1900) based on the same material (see respective remark related to generic diagnosis above). We examined the syntypes, which are in rather bad condition, but we can confirm the presence of a pair of dorsal cirri on segment 3 in both specimens.

In both publications (1876b, 1900) McIntosh described Eusthenelais hibernica and Sthenelais jeffreysi as different species. It is not clear why he did not realise that these are in fact synonymous, as for both species he described the two types of neurochaetae and, although he did not mention the dorsal cirri in the text for $S$. jeffreysi, he clearly figured them in his monograph of 1900 (pl. 29 fig. 4).

Eliason (1962) noted that not only Sthenelais jeffreysi, but also Sthenelais heterochaeta McIntosh, 1897 could be possible synonyms of Eusthenelais hibernica. For S. heterochaeta again the dorsal cirri are not mentioned, but the original description of the elytral and chaetal characters leaves no doubt that this is E. hibernica.

We checked the holotype of $S$. jeffreysi and found it to be unidentifiable; moreover, the type material of $S$. heterochaeta seems to be lost. But, as explained above, the respective original descriptions are sufficient and we confirm Eliason's view that both $S$. jeffreysi and $S$. heterochaeta are synonyms of E. hibernica.

Compared to the other species described herein, Eusthenelais hibernica presents a number of remarkable characters: The presence of a pair of dorsal cirri on segment 3 is the main differentiating character (absent in all other species). The auricles are smaller and much less obvious. The lateral antennae are of similar length to the dorsal tentacular cirri (versus distinctly shorter). The neuropodial posterior bract is large and obvious, similar to the one found in S. limicola (versus smaller and much less obvious in S. boa, or the Fimbriosthenelais species).

\section{Distribution and habitat}

So far only known from the NE Atlantic: recorded from off Norway, along the western coasts of the British Isles and Ireland, down to Southwest Portugal. Occurring on muddy and sandy substrates from 70 to $870 \mathrm{~m}$ depth (see above).

\section{Updated key to the species of Sigalioninae in the Northeast Atlantic and Mediterranean Sea}

We follow the latest subfamily designation proposed by Gonzalez et al. (2018). For keys to other species currently assigned to the subfamilies Pelogeniinae, Pholoinae and Pisioninae, see Barnich \& Fiege (2003), Martinez et al. (2008) and Meißner et al. (2020).

Please note: characters in the key apply to adults; in younger individuals or juveniles there is likely some variation to be observed, for example in the number of stylodes present or the degree of coverage with ventral body papillae. Elytral characters apply to anterior elytra (but not the first pair) unless otherwise stated. The distribution given for species not treated in detail herein is based on Barnich \& Fiege (2003), Wehe (2007) and Núñez et al. (2015). 
1. Median antenna indistinct or very small, without ceratophore. Outer elytral margin extended into digitiform, papillated processes .

- Median antenna present, with distinct ceratophore. Outer elytral margin straight, smooth (i.e., papillae absent) or straight, papillated (papillae simple or dichotomously branched) ..................... 3

2. Elytral marginal processes with about 20 papillae. Large papilla present on anterior side of superior margin of neuropodia (difficult to see in small individuals).

Sigalion mathildae Audouin \& Milne Edwards, 1832

(NE Atlantic, Mediterranean; nearshore)

- Elytral marginal processes with about 10 papillae. Without papilla on neuropodia.

Sigalion squamosus Delle Chiaje, 1830

(NE and SE Atlantic, Mediterranean; nearshore and offshore)

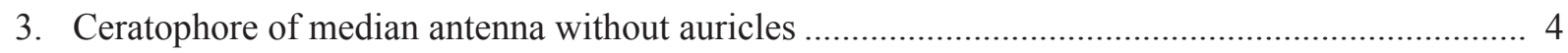

- Ceratophore of median antenna with auricles ...................................................................................... 5

4. Outer elytral margin with irregularly dichotomously branched papillae, elytral surface smooth ......

Euthalenessa oculata (Peters, 1854)

(NE Atlantic: south of Channel to S Africa, Mediterranean, Indian Ocean; nearshore and offshore)

- Elytral margin and surface smooth Leanira hystricis Ehlers, 1874

(NE and SE Atlantic, Mediterranean; nearshore and offshore)

5. Pair of dorsal cirri present on segment 3

- Dorsal cirri absent on segment 3

6. Neurochaetae all spinigers. Outer elytral margin with numerous filiform papillae, elytral surface smooth Neoleanira tetragona (Örsted, 1845)

(Arctic, NE and SE Atlantic; offshore)

- Neurochaetae spinigers and falcigers. Outer elytral margin with several filiform papillae, elytral surface smooth Eusthenelais hibernica McIntosh, 1876

(NE Atlantic: Norway, western British Isles and Ireland, to SW Portugal; offshore)

7. Lateral lips of mouth with obvious labial lobes. Neurochaetae all spinigers. Elytral margin and surface smooth

Labioleanira yhleni (Malmgren, 1867)

(NE Atlantic: south of Channel to W Africa, Mediterranean, Indian Ocean; nearshore and offshore)

- Mouth without labial lobes. Neurochaetae only falcigers or falcigers and spinigers, sometimes a few simple, spinous neurochaetae also present

8. Ventral body surface and parapodial stylodes distinctly papillated

- Ventral body surface and parapodial stylodes smooth (occasionally with minute papillae in parapodia of juveniles or in anteriormost parapodia of adults).

9. Ventral body surface densely papillated. Neuropodial posterior bracts truncate. Outer and posterior elytral margin with numerous short papillae, elytral surface covered by rounded to conical microtubercles....

Fimbriosthenelais zetlandica (McIntosh, 1876)

(NE and SE Atlantic, Mediterranean, Indian Ocean; nearshore and offshore)

- Ventral body surface finely papillated. Neuropodial posterior bracts bilobed. Outer elytral margin with filiform papillae, elytral surface with rounded to conical microtubercles (in anterior elytra surface completely covered, in middle and posterior elytra microtubercles confined to areas near margins) 
10. Outer elytral margin with irregular extensions (anterior elytra) or notched (posterior elytra); elytral surface smooth, except for some microtubercles near anterior margin. Parapodial stylodes slender, cirriform; notopodia with few long dorsal papillae; margins of anterior neuropodial bracts smooth. Notochaetae tapering to simple capillary tip

Sthenelais limicola (Ehlers, 1864)

(NE, NW and SE Atlantic, Mediterranean; nearshore and offshore)

- Outer elytral margin straight, with filiform papillae; elytral surface covered by conical microtubercles. Parapodial stylodes more or less club-shaped; notopodia without long dorsal papillae; margins of anterior neuropodial bracts with digitiform extensions. Notochaetae tapering to simple or minutely bidentate capillary tip

Sthenelais boa (Johnston, 1833)

(NE Atlantic, Mediterranean, Indo-Pacific; nearshore)

\section{Discussion}

The aim of the present study was to revise the Northeast Atlantic sigalionid species assigned to Sthenelais Kinberg, 1856, Fimbriosthenelais Pettibone, 1971 and Eusthenelais McIntosh, 1876. One of the challenges in sigalionid taxonomy is the inconsistent use of the descriptive terminology, especially regarding important differentiating characters, such as lobes, bracts and stylodes found on parapodia, etc. In the Terminology chapter above, we discuss the different terms found in the previous literature and establish a set of standardised definitions, which allows to compare the different species more easily.

The type species of the genus Sthenelais, S. helenae Kinberg, 1856, was revised by Pettibone (1971), but her study did not include two of the earliest described and most common sigalionids in the wider NE Atlantic, Sthenelais boa (Johnston, 1833) and S. limicola (Ehlers, 1864).

Especially $S$. limicola has been inadequately described in the past and we here provide a detailed morphological description allowing us also to add two more species, i.e., S. filamentosus Ditlevsen, 1917 and S. haddoni McIntosh, 1897, to the current list of synonyms. In our study we found that S. limicola presents two remarkable characters, the presence of spinigers in addition to falcigers and of long dorsal papillae on the notopodia, which might justify the erection of a new genus. The phylogenetic study by Gonzalez et al. (2018) seems to confirm our opinion that the current generic assignment of S. limicola should be reconsidered. A more detailed study, combining molecular data of a larger number of species of Sthenelais with the emended diagnostic characters described herein, would be desirable to justify the erection of a new genus for S. limicola. However, currently there are not enough suitable specimens available to conduct such a study.

Sthenelais boa, on the other hand, was suitably described by previous authors (for details, see synonymy section above). However, the discovery of small papillae on the stylodes of parapodia in juveniles (and of anterior parapodia in adults) by Chambers \& Muir (1997) started a discussion on the validity of the genus Fimbriosthenelais established by Pettibone (1971) for species, which differ from Sthenelais by the presence of papillae on their parapodial stylodes. We agree with Chambers \& Muir that minute papillae can be present on stylodes of anterior parapodia in $S$. boa and consequently we include $S$. minor Pruvot \& Racovitza, 1895 in the list of its synonyms. However, we noted that the papillae on the stylodes of F. zetlandica (McIntosh, 1876) and F. longipinnis (Grube, 1869), the two species present in the considered area, are much larger and more easily observed than those found on S. boa (see Fig. 5, presenting stylodes of different species drawn to the same scale). For the time being, we suggest to preserve the status of Fimbriosthenelais and propose that a further study including new species described after Pettibone's revision from other parts of the world and combining morphological and molecular data should be conducted in order to finally decide on the status of this genus.

Based on Eliason (1962), Gil (2011) discussed the potential synonymy of Eusthenelais hibernica McIntosh, 1876 with two deep-water representatives of Sthenelais from the area, S. jeffreysi McIntosh, 1876 and $S$. heterochaeta McIntosh, 1897. Since the type material of E. hibernica is in rather bad condition, 
its validity was questioned by Chambers (1985). Our study revealed that the original description by McIntosh (1876b) and the subsequent description of the same material by McIntosh (1900) are indeed sufficient to differentiate this species and genus and we confirm the validity of Eusthenelais and its type species E. hibernica. Based on additional material recently collected from the Geikie Slide (off Northwest Scotland), we provide an emended diagnosis and description of E. hibernica and confirm the synonymy of $S$. jeffreysi and $S$. heterochaeta with this species.

Another representative of Eusthenelais from deep waters in the Davis Strait, E. abyssicola McIntosh, 1879, was also investigated as part of our revision. We agree with Hartman (1965) and regard this species as indeterminable, its holotype being unidentifiable and the original description being insufficient. This leaves $E$. hibernica to be currently the only valid representative of the genus.

A total of 37 nominal taxa reported to occur in the NE Atlantic and Mediterranean Sea were investigated during this revision and we confirm the validity of five of them: Sthenelais boa and S. limicola, Fimbriosthenelais zetlandica and F. longipinnis, and Eusthenelais hibernica. The above presented results and conclusions provide the necessary basis for a future study combining morphological and molecular data to help resolve the two remaining problems addressed here: firstly, the implications of the occasional presence of minute papillae on the parapodial stylodes of $S$. boa on the validity of the genus Fimbriosthenelais and, secondly, additional proof to determine whether it is justified to erect a new genus for $S$. limicola.

\section{Acknowledgements}

Our special thanks go to the curators of the following museums for making their respective type and other specimens available for this study: Danny Eibye-Jacobsen (Natural History Museum of Denmark, Copenhagen), Dieter Fiege (Senckenberg Museum Frankurt, Germany) and Emma Sherlock (The Natural History Museum, London, United Kingdom). The specimens of the Eurofins AquaSense and Thomson Environmental Consultants' reference collections originate from benthic assessments carried out on behalf of the Centre for Environment, Fisheries and Aquaculture Science (UK), the Joint Nature Conservation Committee (UK), Marine Science Scotland (UK), and Rijkswaterstaat CIV (NL). We would like to thank all staff and responsibles of these institutions for entrusting their material to our study. And finally, we extend our sincere thanks to Danny Eibye-Jacobsen and Dieter Fiege for their very helpful comments on the manuscript and to Geoff Read (National Institute of Water and Atmospheric Research, Wellington, New Zealand) for help in clarifying the confusing publishing date of Sigalion mathildae.

\section{References}

Amoureux L. 1972. Annélides polychètes recueillies sur les pentes du talus continental, au large de la Galice (Espagne). Campagnes 1967 et 1968 de la "Thalassa". Cahiers de Biologie marine 13: 63-89.

Aungtonya C. 2002. A preliminary study of Sigalionidae (Annelida: Polychaeta) from the Andaman Sea off southwestern Thailand, with an overview of presently recognized genera. Phuket Marine Biological Center Special Publication 24: 205-235.

Aungtonya C. 2003. Scanning electron microscopy (SEM) and light microscopy (LM) study of important characters in the identification of Sigalionidae (Annelida: Polychaeta). In: Sigvaldadóttir E., Mackie A.S.Y., Helgason G.V., Reish D.J., Svavarsson J., Steingrímsson S.A. \& Guðmundsson G. (eds) Advances in Polychaete Research. Hydrobiologia 496: 1-16.

https://doi.org/10.1007/978-94-017-0655-1_1

Aungtonya C. \& Eibye-Jacobsen D. 2014. Annotated checklist of the taxa of Sigalionidae and Pholoidae (Annelida: Polychaeta). Phuket Marine Biological Center Special Publication 32: 151-185. 
Aungtonya C. \& Eibye-Jacobsen D. 2018. The genus Fimbriosthenelais Pettibone, 1971 (Sigalionidae: Polychaeta) with the description of a new species from the Andaman Sea. Phuket Marine Biological Center Research Bulletin 75: 1-12.

Barnich R. \& Fiege D. 2003. The Aphroditoidea (Annelida, Polychaeta) of the Mediterranean Sea. Abhandlungen der Senckenbergischen Naturforschenden Gesellschaft 559: 1-167.

Chambers S.J. 1985. Polychaetes from Scottish waters. Part 2. Families Aphroditidae, Sigalionidae, and Polyodontidae. Royal Scottish Museum Studies: 1-38.

Chambers S.J. \& Muir A.I. 1997. Polychaetes: British Chrysopetaloidea, Pisionoidea and Aphroditoidea. Synopses of the British Fauna 54: 1-202.

Claparède E. 1868. Les Annélides chétopodes du Golfe de Naples. Mémoires de la Société de Physique et d'Histoire naturelle de Genève 19 (2): 313-584.

Dalyell J.G. 1853. The Powers of the Creator Displayed in the Creation: or, Observations on Life Amidst the Various Forms of the Humbler Tribes of Animated Nature with Practical Comments and Illustrations. Volume 2. John van Voorst, London.

Day J.H. 1960. The polychaete fauna of South Africa. Part 5. Errant species dredged off Cape coasts. Annals of the South African Museum 45: 261-373.

Ditlevsen H. 1917. Annelids. The Danish Ingolf Expedition 4 (4): 1-71.

Ehlers E. 1864. Die Borstenwürmer (Annelida Chaetopoda) nach systematischen und anatomischen Untersuchungen. 1. Band. Wilhelm Engelmann, Leipzig. https://doi.org/10.5962/bhl.title.2081

Eliason A. 1962. Die Polychaeten der Skagerak-Expedition 1933. Zoologiska Bidrag från Uppsala 33: 207-293.

Fauvel P. 1919. Annélides polychètes de Madagascar, de Djibouti et du Golfe Persique. Archives de Zoologie expérimentale et générale 58: 315-473. https://doi.org/10.5962/bhl.part.8154

Fauvel P. 1923. Polychètes errantes. Faune de France 5: 1-488.

Gil J.C. 2011. The European Fauna of Annelida Polychaeta. Vol. 2. PhD Thesis. University of Lisbon, Portugal.

Gonzalez B.C., Martínez A., Borda E., Iliffe T.M., Eibye-Jacobsen D. \& Worsaae K. 2018. Phylogeny and systematics of Aphroditiformia. Cladistics 34 (3): 225-259. https://doi.org/10.1111/cla.12202

Grube E. 1850. Die Familien der Anneliden. Archiv für Naturgeschichte Berlin 16 (1): 249-364.

Grube E. 1869. Beschreibungen neuer oder weniger bekannter von Hrn. Ehrenberg gesammelter Anneliden des rothen Meeres. Monatsberichte der Königlich Preussischen Akademie der Wissenschaften zu Berlin aus dem Jahre 1869: 484-521. [Imprinted year 1870, but published in 1869 according to The Zoological Record 1870 (vol. 6) for the year 1869].

Guérin-Méneville F.E. 1843. Notice sur un genre d'annélide establi récemment sous le nom Sigalion. Magasin de Zoologie, Paris 3 (Classe VI): 4.

Hartman O. 1959. Catalogue of the polychaetous annelids of the world. Part. I. Occasional Papers, Allan Hancock Foundation Publications 23: 1-353.

Hartman O. 1965. Deep-water benthic polychaetous annelids off New England to Bermuda and other North Atlantic areas. Occasional Papers, Allan Hancock Foundation Publications 28: 1-378.

Hartmann-Schröder G. 1996. Annelida, Borstenwürmer, Polychaeta [Annelida, bristleworms, Polychaeta]. $2^{\text {nd }}$ revised Ed. The fauna of Germany and adjacent seas with their characteristics and ecology 58. Gustav Fischer, Jena, Germany. 
Horst R. 1917. Polychaeta Errantia of the Siboga Expedition, Pt. 2. Aphroditidae and Chrysopetalidae. Siboga-Expeditie Monographie 24 (1b): 45-143.

Johnston G. 1833. Illustrations in British Zoology. Magazine of Natural History and Journal of Zoology, Botany, Mineralogy, Geology and Meterology, London 34: 320-324.

Kinberg J.G.H. 1856. Nya slägten och arter af Annelider. Öfversigt af Kongliga Vetenskaps-Akademiens Förhhandlingar Stockholm 12 (9-10): 381-388 [read 1855; printed 1856].

Leidy J. 1855. Contributions towards a knowledge of the marine Invertebrate fauna of the coasts of Rhode Island and New Jersey. Journal of the Academy of Natural Sciences of Philadelphia 3 (2) (11): $135-152$.

Mackie A.S.Y. \& Chambers S.J. 1990. Revision of the type species of Sigalion, Thalenessa, and Eusigalion (Polychaeta: Sigalionidae). Zoologica Scripta 19 (1): 39-56.

https://doi.org/10.1111/j.1463-6409.1990.tb00239.x

Malmgren A.J. 1866. Nordiska Hafs-Annulata. Öfversigt af Konglia Vetenskaps-Akademiens Förhhandlingar Stockholm 1: 51-110 [read 1865; printed 1866].

Martinez J., Aguirrezabalaga F. \& Adarraga I. 2008. A new species of Pisione (Annelida: Polychaeta: Pisionidae) from circalittoral soft bottoms (SE Bay of Biscay, Basque coast). Cahiers de Biologie marine 49 (3): 283-294.

McIntosh W.C. 1876a. On British Annelida. Part I. Euphrosynidae, Amphinomidae, Aphroditidae, Polynoidae, Acoetidae, and Sigalionidae. Transactions of the Zoological Society London 9 (7): 371-394.

McIntosh W.C. 1876b. On the Annelida of the "Porcupine" Expeditions of 1869 and 1870. Part I. Euphrosynidae, Amphinomidae, Aphroditidae, Polynoidae, Acoetidae, and Sigalionidae. Transactions of the Zoological Society London 9 (8): 395-416.

McIntosh W.C. 1879. On the Annelida obtained during the Cruise of H.M.S. "Valorous" to Davis Strait in 1875. Transactions of the Linnean Society of London, Second Series, Zoology 1 (7): 499-511. https://doi.org/10.1111/j.1096-3642.1878.tb00663b.x

McIntosh W.C. 1897a. Note on Irish annelids in the Museum of Science and Art, Dublin. No. I. Scientific Proceedings, Royal Dublin Society 8 (5): 399-404.

McIntosh W.C. 1897b. Notes from the Gatty Marine Laboratory, St. Andrews, No. XVIII. Annals and Magazine of Natural History 6 (20): 167-178. https://doi.org/10.1080/00222931308693382

McIntosh W.C. 1900. Polychaeta. Amphinomidae to Sigalionidae. A Monograph of the British Annelids 1 (2): 215-444.

Meißner K., Götting M. \& Nygren A. 2020. Do we know who they are? On the identity of Pholoe (Annelida: Sigalionidae: Pholoinae) species from northern Europe. Zoological Journal of the Linnean Society 189 (1): 178-206. https://doi.org/10.1093/zoolinnean/zlz120

Núñez J., Barnich R., Brito M. del C. \& Fiege D. 2015. Familia Sigalionidae Kinberg, 1855. In: Ramos et al. (eds) Annelida Polychaeta IV. In: Parapar J., Moreira J., Núñez J., Barnich R., Brito M. del C., Fiege D., Capaccioni-Azzati R. \& El-Haddad M. Fauna Iberica 41: 216-251. Museo Nacional de Ciencias Naturales, CSIC, Madrid.

Pettibone M.H. 1963. Marine polychaete worms of the New England region. 1. Aphroditidae through Trochochaetidae. U.S. National Museum Bulletin 227 (1): 1-356.

https://doi.org/10.5479/si.03629236.227.1

Pettibone M.H. 1970. Two new genera of Sigalionidae (Polychaeta). Proceedings of the Biological Society of Washington 83 (34): 365-386. 
Pettibone M.H. 1971. Partial revision of the genus Sthenelais Kinberg (Polychaeta: Sigalionidae) with diagnoses of two new genera. Smithsonian Contributions to Zoology 109: 1-40.

https://doi.org/10.5479/si.00810282.109

Potts F.A. 1910. XII. Polychaeta of the Indian Ocean. Part II. The Palmyridae, Aphroditidae, Polynoidae, Acoetidae, and Sigalionidae. Transactions of the Linnean Society, series 2: 13: 325-353.

https://doi.org/10.1111/j.1096-3642.1910.tb00519.x

Pruvot G. \& Racovitza E.G. 1895. Matériaux pour la faune des Annélides de Banyuls. Archives de Zoologie expérimentale et générale, série 3 3: 339-492.

Quatrefages M.A. de 1866. Annélides et Géphyriens. Histoire naturelle des Annelés marins et d'eau douce, Volume 1. Librairie Encyclopédique de Roret, Paris [imprinted date 1865, but published 1866, see Wright 1867].

Rathke H. 1843. Beiträge zur Fauna Norwegens. Nova Acta Academiae Caesareae LeopoldinoCarolinae Naturae Curiosorum 20, Breslau and Bonn.

Read G. \& Fauchald K. (eds). 2020. World Polychaeta database. Eusthenelais McIntosh, 1876. Available from http://www.marinespecies.org/ [accessed Apr. 2020].

Rullier F. 1964. Annélides polychètes. Campagne de la Calypso: Îles du Cap Vert. Résultats scientifiques des Campagnes de la Calypso 6: 113-218.

Saint-Joseph A. de 1899. Annélides polychètes de la rade de Brest et de Paimpol. Annales des Sciences naturelles 8 (10): 161-194.

Schmarda L.K. 1861. Neue Turbellarien, Rotatorien und Anneliden beobachtet und gesammelt auf einer Reise um die Erde 1853 bis 1857. Neue Wirbellose Thiere Beobachtet und Gesammelt auf einer Reise um die Erde 1853 bis 18571 (2): 1-164.

Wehe T. 2007. Revision of the scale worms (Polychaeta: Aphroditoidea) occurring in the seas surrounding the Arabian Peninsula. Part II. Sigalionidae. Fauna of Arabia 23: 41-124.

Wright E.P. 1867. Annelida. Zoological Record 3: 578.

Manuscript received: 16 November 2020

Manuscript accepted: 25 January 2021

Published on: 29 March 2021

Topic editor: Rudy C.A.M. Jocqué

Desk editor: Kristiaan Hoedemakers

Printed versions of all papers are also deposited in the libraries of the institutes that are members of the EJT consortium: Muséum national d'histoire naturelle, Paris, France; Meise Botanic Garden, Belgium; Royal Museum for Central Africa, Tervuren, Belgium; Royal Belgian Institute of Natural Sciences, Brussels, Belgium; Natural History Museum of Denmark, Copenhagen, Denmark; Naturalis Biodiversity Center, Leiden, the Netherlands; Museo Nacional de Ciencias Naturales-CSIC, Madrid, Spain; Real Jardín Botánico de Madrid CSIC, Spain; Zoological Research Museum Alexander Koenig, Bonn, Germany; National Museum, Prague, Czech Republic. 